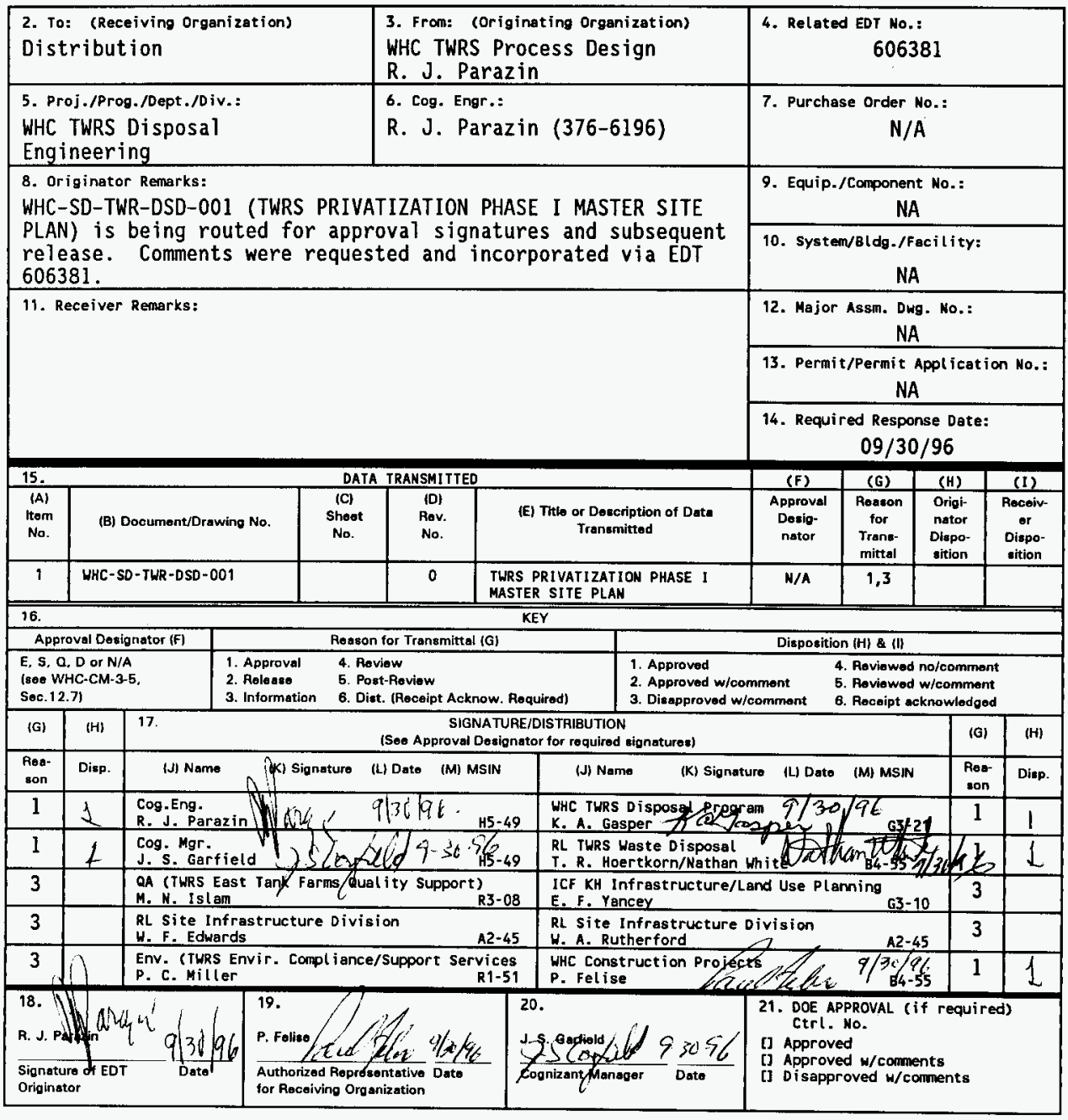




\title{
TWRS PRIVATIZATION PHASE 1 MASTER SITE PLAN
}

\author{
R. J. Parazin
}

Westinghouse Hanford Company, Richland, WA 99352

U.S. Department of Energy Contract DE-AC06-87RL10930

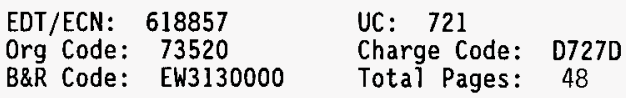

Key Words: TWRS Privatization, Phase 1, site development, grout site, privatization utilities, master site plan,

Abstract: The DOE-RL is pursuing a new business strategy of hiring private contractors for treatment of Hanford Site tank wastes. This strategy is called 'privatization' and includes design, permitting, construction, operation and deactivation of facilities for tank waste treatment. The TWRS Privatization Infrastructure Project consists of several sub-projects which will provide key services needed to support the privatization mission. This master site plan presently describes all pertinent aspects of the site and identifies all planned provisions for site development, utilities and other site services. It is a baseline document which will be revised as privatization proceeds through design, construction and start-up.

TRADEMARK DISCLAIMER. Reference herein to any specific commercial product, process, or service by trade name, trademark, manufacturer, or otherwise, does not necessarily constitute or imply its endorsement, recomendation, or favoring by the United States Government or any agency thereof or its contractors or subcontractors.

Printed in the United States of America. To obtain copies of this document, contact: WHC/BCS Document Control Services, P.O. Box 1970, Mailstop H6-08, Richland WA 99352, Phone (509) 372-2420; Fax (509) 376-4989.
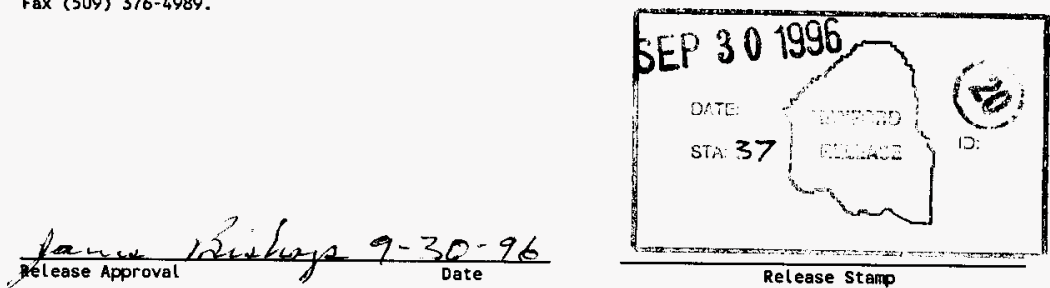

\section{Approved for Public Release}


WHC-SD-TWR-DSD-001

Revision 0

\section{TWRS PRIVATIZATION PHASE I \\ MASTER SITE PLAN}

WORK ORDER E23382

Prepared for

Westinghouse Hanford Company

September 1996

Subcontract WHC 380393

Prepared by

ICF Kaiser Hanford Company

Richland, Washington

E23382ES 


\title{
TWRS PRIVATIZATION PHASE I
}

\section{MASTER SITE PLAN}

\author{
WORK ORDER E23382
}

\author{
Prepared by \\ ICF Kaiser Hanford Company \\ Richland, Washington
}

for

Westinghouse Hanford Company

September 1996

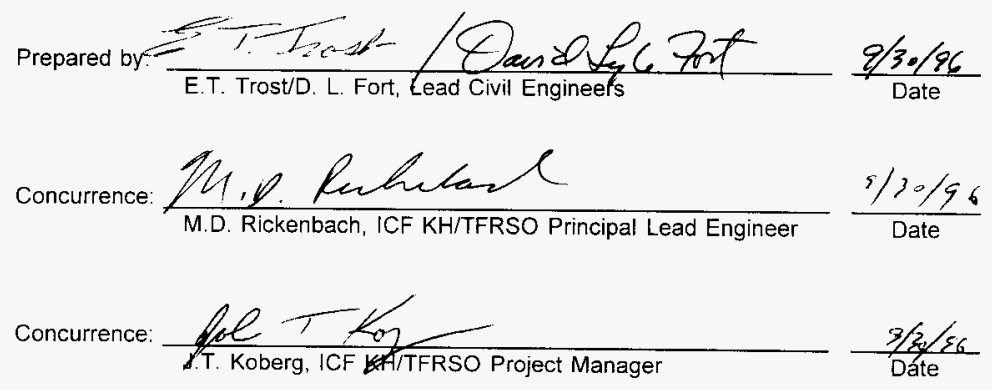




\section{TWRS PRIVATIZATION PHASE I - MASTER SITE PLAN}

\section{EXECUTIVE SUMMARY}

The U.S. Department of Energy (DOE) has chosen to accomplish the Tank Waste Remediation System disposal mission via privatization. The disposal mission has been divided into two privatization phases. Phase $\mathrm{I}$, a 'proof of concept' phase, will establish and demonstrate the technical, commercial, and procurement capabilities necessary for privatization to proceed. Once established on this relatively small scale, privatization will be expanded, through a second competition, in the form of a second phase (Phase II) to dispose of the remainder of the tank waste.

In conjunction with preparation of the Tank Waste Remediation System (TWRS) Privatization Request for Proposals (RFP)(RL, 1996), a location was selected for the Phase I demonstration facilities (Shord, 1996). The location selected was the area previously developed and characterized for the Grout Disposal Site, adjoining the 200 East Area. The site is of sufficient size for two competing Private Contractors (PC) to carry out pretreatment, immobilization, and vitrification operations and possesses the required characteristics (e.g., close to feed tanks) to best facilitate the Phase I operations.

An overall long-range Master Site Plan (MSP) has been developed to establish a "baseline" for the (TWRS) Privatization Phase I (TPPI) PC Sites. The MSP depicts the recommended layout for the PC Sites along with various interfaces between the sites and other Hanford utilities and functions. The complete integration of TPPI MSP with overall Hanford Site planning process will assist in establishing the PC sites and the necessary priorities to meet the Hanford cleanup mission.

The MSP has been developed systematically into a comprehensive, safe, flexible, logical and cost-effective plan. The general philosophy behind the preparation of a MSP for the TPPI program is that it will serve as a single source documentation of the planning for the development of the TPPI complex. The effort will plan temporary and permanent land use, utilities, and traffic flow for the overall program. It will identify needs, requirements and conflicts. As such, it is not a static, one-time effort. Rather, it is a flexible plan which should be constantly maintained to reflect the latest long term program plans.

Consequently, it is important that this report document the methodology employed for the long term maintenance of the MSP. The most important conclusions and recommendations of the recent engineering studies have been incorporated into this document. As the TPPI program's technical details become established, project definitions are changed, and new data becomes available, the MSP should be updated accordingly and this report will serve as a point of reference. 


\section{TABLE OF CONTENTS}

1.0 INTRODUCTION $\ldots \ldots \ldots \ldots \ldots \ldots \ldots \ldots \ldots \ldots \ldots \ldots \ldots \ldots \ldots$

2.0 PURPOSE AND BACKGROUND $\ldots \ldots \ldots \ldots \ldots \ldots \ldots \ldots \ldots \ldots$

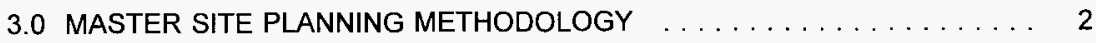

4.0 PLANNING BASIS CRITERIA AND ASSUMPTIONS $\ldots \ldots \ldots \ldots \ldots$

5.0 EXISTING CONDITIONS $\ldots \ldots \ldots \ldots \ldots \ldots \ldots \ldots \ldots \ldots \ldots$

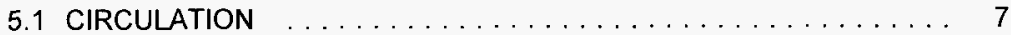

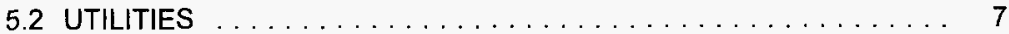

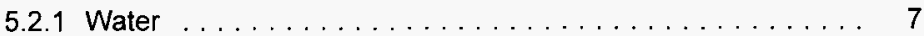

5.2 .2 Telecommunications $\ldots \ldots \ldots \ldots \ldots \ldots \ldots \ldots$

5.2 .3 Electrical $\ldots \ldots \ldots \ldots \ldots \ldots \ldots \ldots \ldots \ldots \ldots$

5.2 .4 Steam ........................ 8

5.2 .5 Sanitary Wastewater Systems $\ldots \ldots \ldots \ldots \ldots \ldots \ldots$

5.2 .6 Utilities Summary $\ldots \ldots \ldots \ldots \ldots \ldots \ldots \ldots$

5.3 SITE CHARACTERIZATION AND ENVIRONMENTAL BASELINE $\ldots .9$

5.3.1 Site Characterization and Environmental Baseline DQO Task ......................... 9

5.3.2 Preparation of Site Characterization and Environmental Baseline Plan ...................... 10

5.3.3 QUALITY ASSURANCE . . . . . . . . . . . . . . 10

6.0 MASTER SITE PLAN DEVELOPMENT $\ldots \ldots \ldots \ldots \ldots \ldots \ldots \ldots \ldots$

6.1 SITE DEVELOPMENT $\ldots \ldots \ldots \ldots \ldots \ldots \ldots \ldots \ldots \ldots \ldots$

6.1 .1 Parcel Size . . . . . . . . . . . . . . . . . . 13

6.1.2 Parcel Orientation ................... 13

6.1 .3 Uncertainties . . . . . . . . . . . . . . . . . . . . . 13

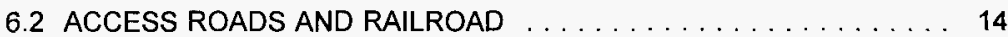

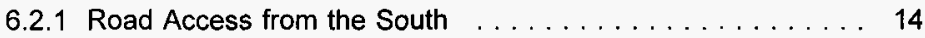

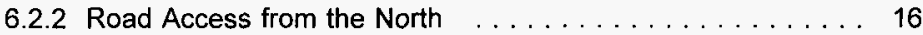

6.2 .3 Railroad Access ...................... 16

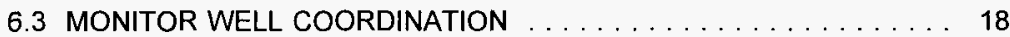

6.3.1 Wells Compromised by PC Construction Activities ...... 18

6.4 LOW-LEVEL WASTE INTERIM STORAGE COORDINATION $\cdots .$.

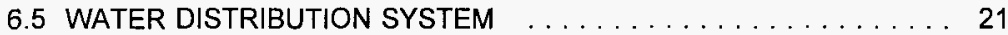

6.6 ELECTRICAL DISTRIBUTION SYSTEM $\ldots \ldots \ldots \ldots \ldots \ldots \ldots \ldots$

6.7 EFFLUENT COLLECTION AND DISPOSAL SYSTEM $\ldots \ldots \ldots .23$

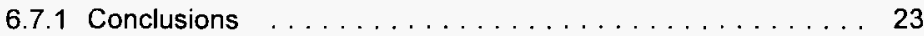

6.7.2 Externally Imposed Constraints ............. 23

6.7.3 Treatment Facility Influent Restrictions $\ldots \ldots \ldots \ldots \ldots 27$ 
TABLE OF CONTENTS (continued)

6.8 TRANSFER LINES/FEED LINES $\ldots \ldots \ldots \ldots \ldots \ldots \ldots \ldots \ldots .28$

6.9 CONSTRUCTION PHASING $\ldots \ldots \ldots \ldots \ldots \ldots \ldots \ldots$

8.0 MASTER SITE PLAN MAINTENANCE $\ldots \ldots \ldots \ldots \ldots \ldots \ldots$

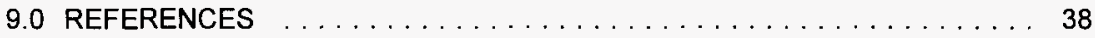

FIGURES

FIGURE 1. HANFORD SITE MAP $\ldots \ldots \ldots \ldots \ldots \ldots \ldots \ldots \ldots \ldots$

FIGURE 2. AERIAL PHOTOGRAPH OF 200 EAST AREA $\ldots \ldots \ldots \ldots \ldots 5$

FIGURE 3. 200 EAST AREA FACILITIES $\ldots \ldots \ldots \ldots \ldots \ldots \ldots \ldots \ldots$

FIGURE 4. AERIAL VIEW OF THE PREFERRED SITE LAYOUT $\ldots \ldots \ldots \ldots 11$

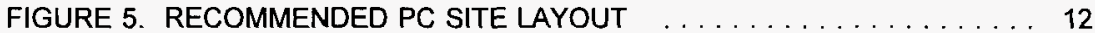

FIGURE 6. PREFERRED ACCESS ROAD LOCATIONS $\ldots \ldots \ldots \ldots \ldots \ldots .15$

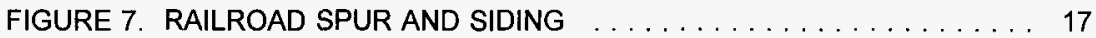

FIGURE 8. POTENTIALLY COMPROMISED MONITORING WELLS $\ldots \ldots \ldots 19$

FIGURE 9. RECOMMENDED RAWIPOTABLE WATER LINE ROUTES . . . . 22

FIGURE 10. ELECTRICAL POWER TRANSMISSION ROUTE . . . . . . . 24

FIGURE 11. RADIOACTIVE, DANGEROUS EFFLUENT ROUTE . . . . . . 25

FIGURE 12. NON-RADIOACTIVE, NON-DANGEROUS EFFLUENT ROUTE . . 26

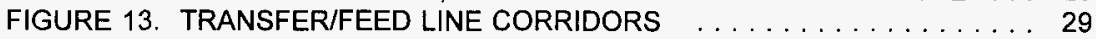

FIGURE 14. TEMPORARY CONSTRUCTION WATER AND POWER $\ldots \ldots \ldots .30$

FIGURE 15. SCHEDULE $\ldots \ldots \ldots \ldots \ldots \ldots \ldots \ldots \ldots \ldots \ldots \ldots \ldots \ldots \ldots$

FIGURE 16. MASTER SITE PLAN $\ldots \ldots \ldots \ldots \ldots \ldots \ldots \ldots \ldots \ldots \ldots$ 


\section{ABBREVIATIONS}

$\begin{array}{ll}\text { ALARA } & \text { As Low As Reasonably Achievable } \\ \text { CX } & \text { Categorical Exclusion } \\ \text { CWA } & \text { Clean Water Act } \\ \text { DOE } & \text { U.S. Department of Energy } \\ \text { DOE-RL } & \text { U.S. Department of Energy, Richland Operations Office } \\ \text { DQO } & \text { Data Quality Objectives } \\ \text { EA } & \text { Environmental Assessment } \\ \text { ECOLOGY } & \text { Washington State Department of Ecology } \\ \text { ETF } & \text { Effluent Treatment Facility } \\ \text { FY } & \text { Fiscal Year } \\ \text { gpm } & \text { gallons per minute } \\ \text { HLAN } & \text { Hanford Local Area Network } \\ \text { HLW } & \text { High-level waste } \\ \text { HDPE } & \text { High Density Polyethylene } \\ \text { ILLW } & \text { Immobilized Low-level Waste } \\ \text { KV } & \text { kilovolts } \\ \text { LERF } & \text { Liquid Effluent Retention Facility } \\ \text { Ipm } & \text { liters per minute } \\ \text { LLW } & \text { Low-level waste } \\ \text { mm } & \text { millimeters } \\ \text { M\&I } & \text { Hanford Site Maintenance and Integration Contractor } \\ \text { MSP } & \text { Master Site Plan } \\ \text { MVA } & \text { megavolt-ampere } \\ \text { MW } & \text { megawatt } \\ \text { NEPA } & \text { National Environmental Policy Act } \\ \text { NFPA } & \text { National Fire Protection Association } \\ \text { pSi } & \text { pounds per square inch } \\ \text { PC } & \text { Privatization Contractor } \\ \text { PVC } & \text { Poly Vinyl Chloride } \\ \text { QA } & \text { Quality Assurance } \\ \text { QAPP } & \text { Quality Assurance Project Plan } \\ \text { RCRA } & \text { Resource Conservation and Recovery Act } \\ \text { RFP } & \text { Request for Proposal } \\ \text { RSUs } & \text { Remote Switching Units } \\ \text { SPIF } & \text { Systematic Planning of Industrial Facilities } \\ \text { SSAS } & \text { Subsurface soil absorption system } \\ \text { TEDF } & \text { Treated Effluent Disposal Facility } \\ \text { TPPI } & \text { TWRS Privatization Phase I } \\ \text { TWRS } & \text { Tank Waste Remediation System } \\ \text { WAC } & \text { Washington Administrative Code } \\ & \\ & \end{array}$




\subsection{INTRODUCTION}

The primary function of 200 Areas facilities was processing of nuclear material for defense purposes. This activity resulted in liquid radiological wastes which were stored in tank farms located in several places in both the 200 East and West Areas. High-level waste (HLW) has been stored in large underground storage tanks at the Hanford Site since 1944. Approximately 55 million gallons of waste are currently being stored in 177 tanks. These caustic wastes consist of many different chemicals in the form of liquids, slurries, saltcakes, and sludges. In 1992, the TWRS Program was established to manage, retrieve, treat, immobilize, and dispose of these wastes in a safe, environmentally-sound, and cost-effective manner.

In pursuing the concept of privatizing the TWRS, the Department of Energy (DOE) is proposing to change its contracting approach to the purchase of products from a contractor-owned, contractor operated facility under a fixed-price type of contract. The underlying intent is to transfer a significant share of the responsibility, accountability, and liability for completing the remediation effort to Private Contractors.

Not all functions within the TWRS are suitable for privatization. The functions considered privatizable include the retrieval, transfer, pretreatment, low-activity waste vitrification, high-level waste vitrification and interim storage of the vitrified high-level waste. Under the Tri-Party Agreement, the 149 single-shell tanks must be emptied by 2018 and the 28 double-shell tanks must emptied by 2028 . All processing must be completed by 2028. Other benchmark milestones include the following: Low-activity waste pretreatment must begin by 2002 , low-activity waste immobilization must begin by 2002 , and high-level waste vitrification must begin by 2009 . This schedule may be subject to change as a result of the latest DOE draft guidance direction for the 10-year plan (Alm, 1996).

Under a privatized approach, the Private Contractors are unwilling to commit immediately to full-scale facilities on a fixed-price basis because of the current uncertainties with regard to waste characteristics, the effectiveness of their technology with Hanford waste, and regulatory framework for protection of workers and the general public. The DOE is also faced with uncertainties including the specifications against which to purchase the deliverables, the basis for accepting the deliverables, the structure of the contract and the basis for handling change orders. Consequently the approach to privatization will be conducted in two phases. The first phase will be a Proof-of-Concept-Commercial Demonstration Phase.

The first phase will involve the pretreatment, low-level waste vitrification of approximately 6-13 percent of the waste over a five year period. High-level waste separated in the pretreatment process would either be stored on an interim basis until sufficient quantities are collected to make it cost effective to process or immobilized as an option in the initial phase. The Proof-of-Concept/Commercial Demonstration Phase (Phase I) would select multiple contractors to design and permit facilities, assuring competition and facilitate 
cost control. There is the potential these contractors may provide the high-level waste immobilization option. The objectives of Phase are to: demonstrate technologies and processes in a production-level environment, treat and immobilize sufficient waste to demonstrate early progress in remediating the tank situation to the stakeholder, understand better the costs, risks, and benefits of a fixed-price privatization framework, ascertain the financial viability of the private marketplace to accomplish the TWRS mission, establish conditions for the DOE to be a "smart buyer" and for private industry to be a "smart provider" of treated waste products for Phase II.

The second phase will be the Full-Scale production phase. Facilities will be sized so all of the remaining waste can be processed and immobilized on a schedule that will accommodate removing the waste in single-shell tanks by 2018 .

\subsection{PURPOSE AND BACKGROUND}

The purpose of an overall long-range Master Site Plan (MSP) is to visualize and physically integrate the planning "baseline" for the Tank Waste Remediation System (TWRS) Privatization Phase I Site, identify the common functions for the individual PC sites and interfaces between those sites and other Hanford functions and infrastructure.

A location adjoining the 200 East Area, that was previously developed and characterized for the Grout Disposal Site, was selected for the Phase I demonstration facilities (Shord, 1996). The site is of sufficient size for two competing PC(s) to carry out pretreatment, immobilization, and vitrification operations and possesses the required characteristics (e.g., close to feed tanks) to best facilitate the Phase I operations, see Figure 1, for the TWRS Phase I Site location.

The MSP defines the specific PC sites and integration of the various elements such as; the coordination of the groundwater monitoring wells, access roads, railroad access, temporary construction and permanent electrical power, water, effluent collection, site services and waste transfer lines.

The MSP has been prepared in a format suitable for public release as a supporting document. The Related information drawing database (e.g., AutoCad 3rd party software) has been prepared in a file format compatible with the other interface drawings (water, electricity, effluents, etc.) for ease of integration and are under configuration control.

\subsection{MASTER SITE PLANNING METHODOLOGY}

Site planning principles "Systematic Planning of Industrial Facilities (S.P.I.F.)" (Muther, 1988), as presented by Richard Muther in his September, 1994 DOE/RL sponsored seminar was used to develop the MSP. 


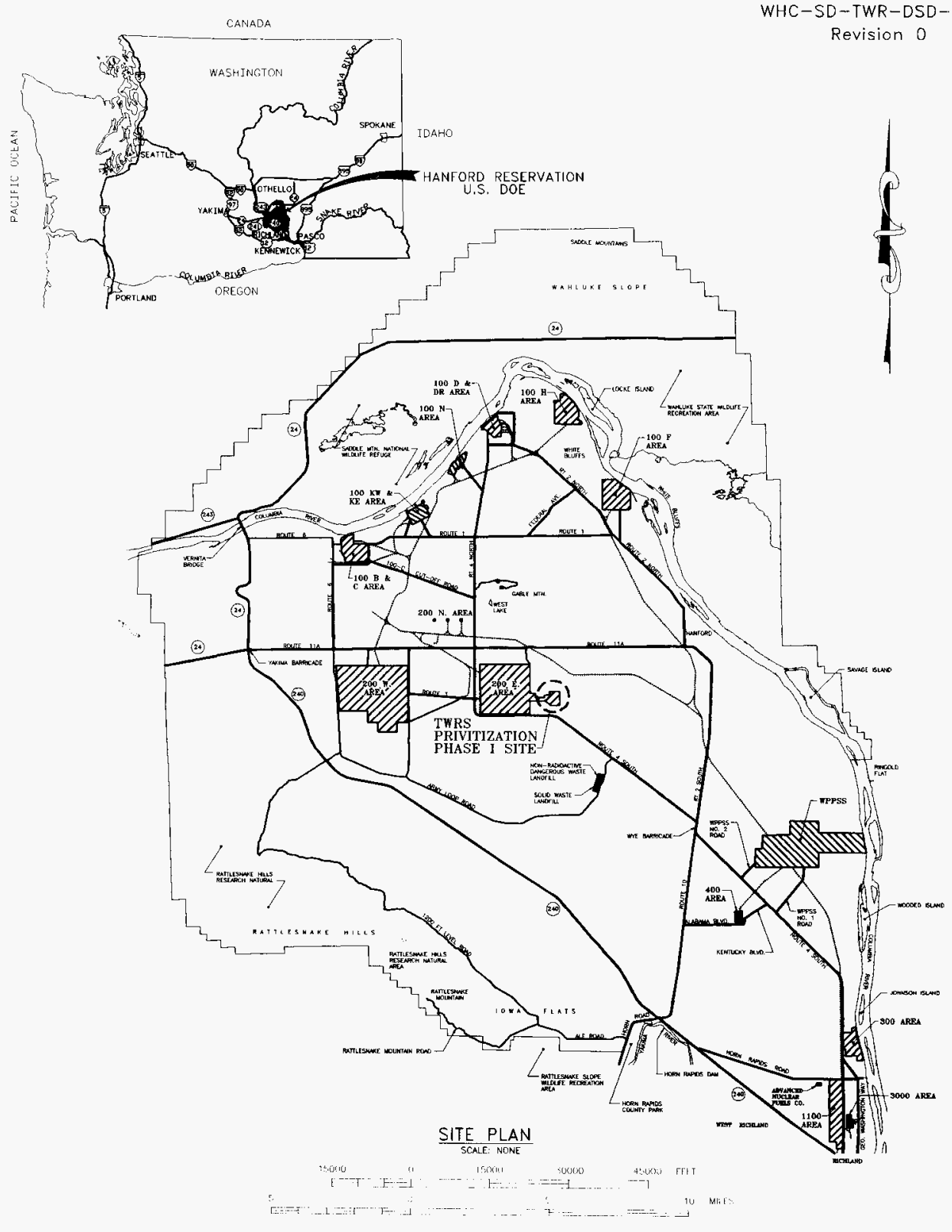

FIGURE 1. HANFORD SITE MAP 
The SPIF planning process is a proven approach. The process sets forth five sequential steps that progress from inputs and influences to a specific plan, with a check-and coordinate at each step. The process has flexibility in its application, serving as a guide rather that a specific set of instructions. The process involves interaction, integration and modification of each component. The process incorporates the need for analysis, coordination or control by other parties outside the planning project but related to it. A detailed description of the five sequential site development planning steps is included in the Site Development Engineering Study (Fort, 1996). In addition to integrating all five physical components, the many physical and non-physical influences outside the direct planning have been considered.

\subsection{PLANNING BASIS CRITERIA AND ASSUMPTIONS}

Goals and objectives of the MSP should be established first to ensure the Master Site Planning efforts are properly focused on the correct mission.

The program values are defined and the environmental, health, safety, operational interfaces, infrastructure considerations, construction phasing and long range planning criteria are established.

The criteria as presented in the Site Development Engineering Study was used to develop the MSP. The criteria is based on detailed project input, existing conditions, SPIF planning principles, and Hanford planning criteria. In some cases where existing information is not available, or felt unreliable, assumptions were made.

\subsection{EXISTING CONDITIONS}

The 200 East Area contains many existing facilities, see Figure 2 for an aerial perspective of the 200 East Area looking to the west. A drawing of the 200 East Area Facilities has also been included, see Figure 3.

Existing utilities are discussed in this section on a general level only, except for source and areas of routing conflict. Utilities supplying existing facilities are expected to be required well into the future. The Hanford 200 Area Development Plan, (Rinne, 1993) served as the main source of reference information for this section.

The Facilities Upgrade (Restoration) Program of the early 1980's provided many important improvements to systems. The systems that received improvements remain in good condition today, but the systems that did not receive improvements can be rated only as fair to poor. 


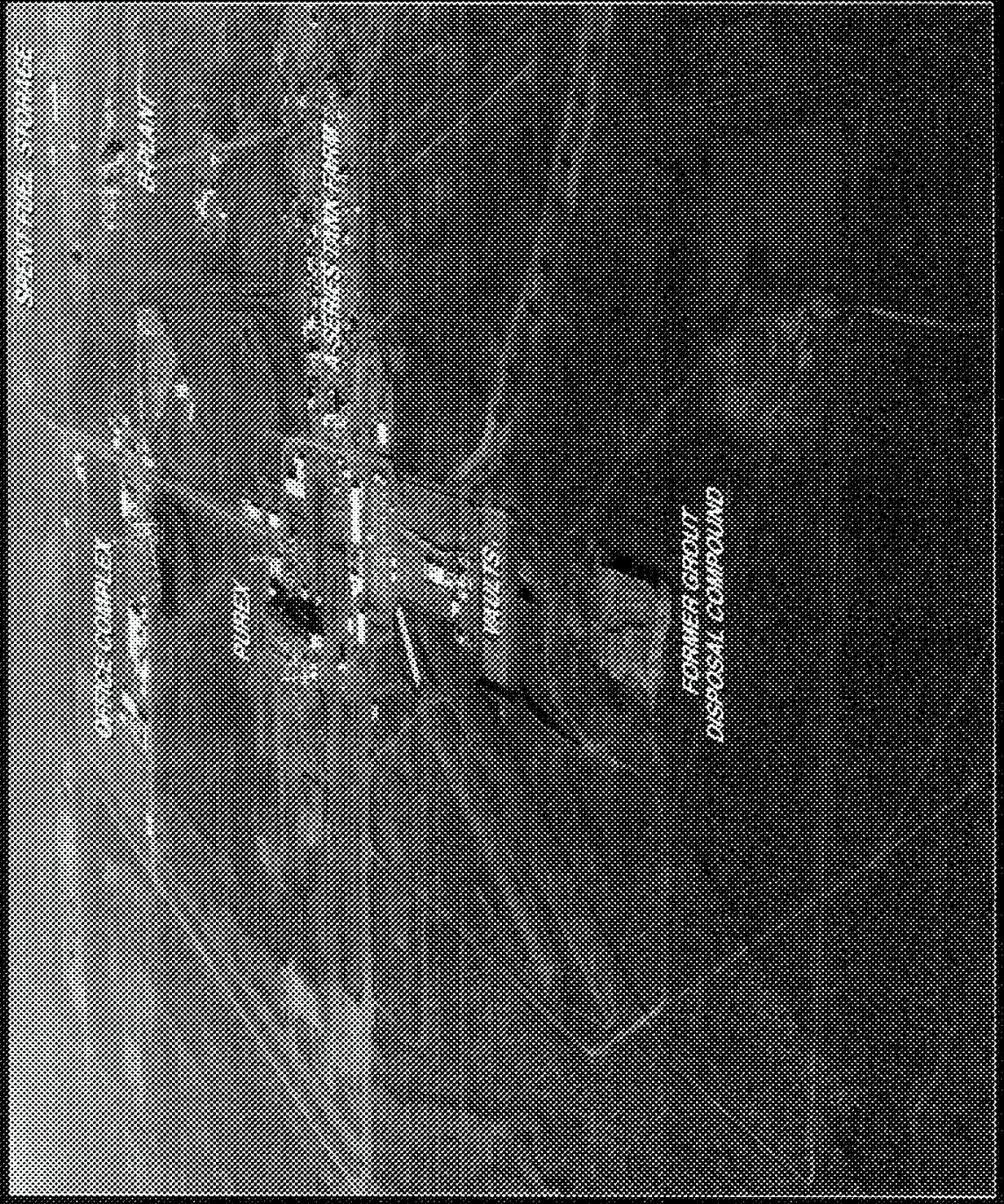

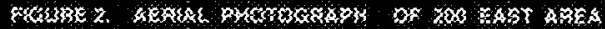




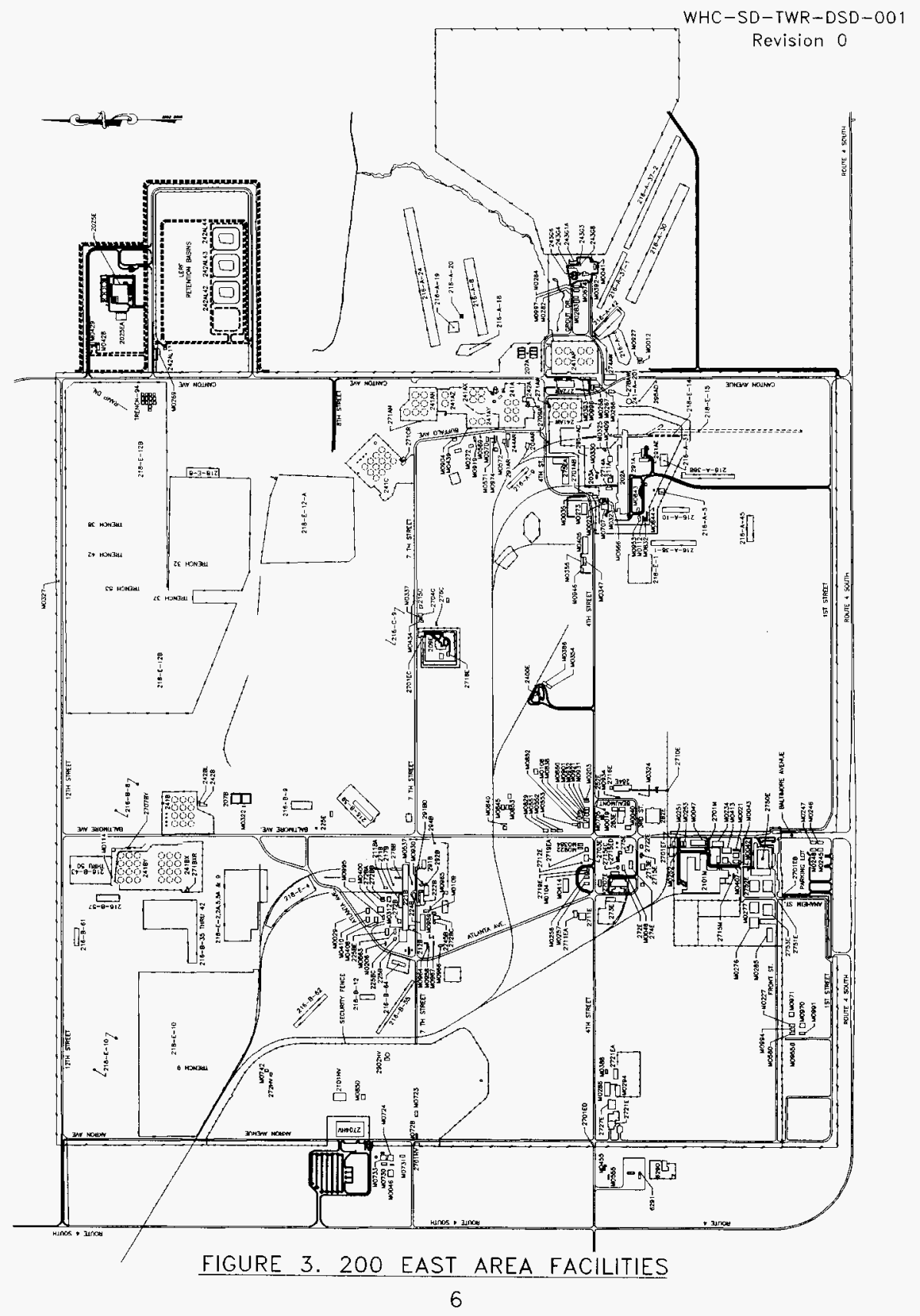




\subsection{CIRCULATION}

The main access from the south is via the Wye Barricade using Route 4S. A secondary access via the Wye Barricade is Route $2 S$ to Route $11 \mathrm{~A}$. The main access road to this area from the north via the Yakima Barricade is Route $11 \mathrm{~A}$ directly or by combinations of Route $11 \mathrm{~A}$ and Route 3 or Route $4 \mathrm{~S}$. Access to the 200 East Area is via former gate 810 at the northeast corner, 814 on the west side, and from Canton Avenue on the south side.

The roads within the 200 East Area run in a broken grid pattern; the north-south roads are named for cities and the east-west roads are numbered. These roads generally travel short distances and are commonly broken by prior expansions to major operating facilities. Many of the roadways in the 200 East Area need to be resurfaced. In addition, many of the roadways are used for pedestrian traffic because of the lack of sidewalks. The condition of these roads ranges from fair to poor.

Private parking in the 200 East Area is primarily located at each facility with adequate walkways to the buildings.

Approximately $24.0 \mathrm{~km}$ ( $14.9 \mathrm{mi}$ ) of railroad track runs within the 200 Areas. The rail system transports coal to the power houses, waste to burial grounds, and equipment and materials to major work centers. The railroad system trackage is generally sound. Maintenance levels vary with use. For instance the spurs to the power houses are well maintained while some sections of track through burial grounds are covered with potentially contaminated blow sand.

When the existing burial grounds will be closed and covered some roads and rail lines adjacent to these burial grounds will need to be relocated to allow room for the toes of the burial ground covers.

\subsection{UTILITIES}

This section identifies utilities serving the 200 Areas. Utilities include water, telecommunications, electrical, steam, and sewer.

\subsubsection{Water}

Much of the 200 Areas water systems were constructed in 1944. Systems were designed to support the high demand chemical processing operations. New requirements for water are expected to be met by the capacities made available by the reduction in chemical processing requirements. For instance, 4,000 to $6 ; 000 \mathrm{gpm}$ of capacity will become available for other use upon conclusion of activities at PUREX.

The existing 200 Areas water systems are expected to continue to serve the areas for the foreseeable future. Supply, storage, pumping, and distribution components will be evaluated continually for adequacy and condition to ensure the availability of raw and 
sanitary water to activities in these areas. Replacement of the majority of the 27 miles of steel piping will probably be required before the 200 Area cleanup is completed.

\subsubsection{Telecommunications}

Telephone and some data service will be provided by Remote Switching Units (RSUs) located in the 200 East and 200 West Areas. These RSUs will be connected via a fiber optic network to the Host switching location within the 300 Area. Site space allocation will be required for the RSUs within 200 East and West Areas. Intra-area HLAN data traffic will also use the interconnecting fiber optic cables for transmission of data.

Future facility requirements to support the telecommunications needs for the 200 Areas will consist of identifying and providing telecommunications rooms within building space to accommodate operating requirements for these various types of telecommunications equipment. This building space is required to be identified and provided on all new and existing (remodeled) structures within the 200 Areas.

Also required will be routing capability (easements), for main route fibers to interconnect the Host Switching System and the RSUs, the HLAN and distribution routing to the new service locations.

\subsubsection{Electrical}

Power to the 200 Areas comes from the 251-W Substation located just north of Route $11 \mathrm{~A}$ and approximately 1.4 mi west of Route 4 North. This substation is part of the Hanford 230-kV transmission loop.

The 251-W Substation has two 230-kV buses and two 230-kV to 13.8-kV transformers, each with a maximum rating of $50 \mathrm{MVA}$. Two $13.8-\mathrm{kV}$ switchgear buses distribute $13.8-\mathrm{kV}$ electrical power to the 200 Areas via overhead distribution power lines. Critical services are supplied electrical power by two distribution circuits, one from each of the 13.8-kV buses. The normally open $13.8-\mathrm{kV}$ bus-tie breaker keeps both of the $13.8-\mathrm{kV}$ buses independent. The two $230-\mathrm{kV}$ power sources from two sides of the substation provide a reliable energy supply. The current peak demand at the 251-W Substation is $18 \mathrm{MW}$. The distribution system is generally in fair to good condition.

\subsubsection{Steam}

Heating and process steam is supplied from two powerhouses, one in each area. The 200 East Area powerhouse has five coal-fired boilers rated at a total of $325,000 \mathrm{lb} / \mathrm{h}$, and a short-term overload rating of $345,000 \mathrm{lb} / \mathrm{h}$ for four hours.

The existing steam plants, constructed in 1943, will not meet future space heating and process needs. As the 200 Areas will serve as the primary area for waste treatment and long-term storage, a reliable steam supply is a critical element of Hanford Operations. 
The most recent plan is to decentralize the steam system in FY 1997, with a number of package boilers being located at strategic locations. All new developments will be required to provide their own steam.

\subsubsection{Sanitary Wastewater Systems}

Sanitary sewer effluents in the 200 Areas have been managed exclusively through the use of septic tanks and subsurface soil absorption systems (SSAS) since 1943. There are approximately 44 individual septic tanks and drainfields currently serving 200 Area facilities. Holding tanks are used for some small flow generation areas in lieu of septic tank systems. Some systems have failed and require regular pumping. This must continue until approvals can be obtained for installation of replacement septic systems.

\subsubsection{Utilities Summary}

The 200 Areas infrastructure is approaching $\mathbf{5 0}$ years old. It will continue to be required throughout the foreseeable future. Significant portions of each infrastructure system will need to be replaced or upgraded in the future.

Generally line item projects include provision of necessary links to existing infrastructure. However, in situations where several projects are foreseen in the same general location, it may make good fiscal sense to provide the infrastructure as part of a single project. This approach should also be considered for application for the proposed TWRS Phase I and II Complexes.

\subsection{SITE CHARACTERIZATION AND ENVIRONMENTAL BASELINE}

This section summarizes the tasks necessary to adequately characterize and establish an environmental baseline for the site selected for the TPPI demonstration site. This characterization is necessary prior to release of the site to private contractors who will design, construct, and operate Phase I demonstration facilities (Reidel, 1996).

The Site Characterization and Environmental Baseline Plan is an assessment and determination of the Phase I site and environmental data needs using the Data Quality Objectives (DQO) approach. The DQO process will ensure that only necessary and relevant data are acquired. This plan also will determine what data is required for preoperational monitoring to establish an environmental baseline prior to operation. The Site Characterization and Environmental Baseline Plan will be completed in two stages: Site Characterization and Environmental Baseline DQO Task, and Preparation of Site Characterization and Environmental Baseline Plan.

\subsubsection{Site Characterization and Environmental Baseline DQO Task}

The DQO process will be used to determine the data necessary to adequately characterize the site for its intended use and establish an environmental baseline using 
pre-operational monitoring. The types of data that will be inputs to the decision include, but are not limited to, the following:

1) Site Survey;

2) Soil sampling for chemicals and radionuclides of surface and vadose zone;

3) Surface radiological survey;

4) Review of existing information from the Grout Project;

5) Ground Penetrating Radar survey (near surface $(10 \mathrm{~m})$ features);

6) Groundwater information.

7) Shallow $(<10 \mathrm{~m})$ borings.

The output of the DQO process will be a Sampling and Analysis Plan for site characterization and pre-operational monitoring.

\subsubsection{Preparation of Site Characterization and Environmental Baseline Plan}

Once the DQO process is complete the Site Characterization and Environmental Baseline Plan will be constructed describing the types of data that exists and the data needed. The additional data required will be described along with the quantity of data, the quality of the required data, and a Sampling and Analysis Plan for collecting the data. The Sampling and Analysis Plan will describe the methods and sampling design.

\subsubsection{QUALITY ASSURANCE}

The Quality Assurance plan applicable to WHC environmental activities is described in WHC-CM-7-7 and WHC-CM-7-8. Deliverables will be reviewed and approved by Quality Assurance in accordance with accepted WHC QA practices. The Site Characterization and Environmental Baseline Plan will have a Quality Assurance Project Plan (QAPP) for the Sampling and Analysis Plan.

\subsection{MASTER SITE PLAN DEVELOPMENT}

The TWRS Privatization Phase I Site Evaluation Report (Shord, 1996). recommended that the TWRS Phase I PC sites be located in the area previously developed for the Grout Disposal.

\subsection{SITE DEVELOPMENT}

A large mound of soil left behind by the grout vault excavation operations is located near the center of the former Grout Disposal Site, see Figure 4. In the preferred layout, one PC site is located north of the soil mound and the other site is located on the south side, see Figure 5. 


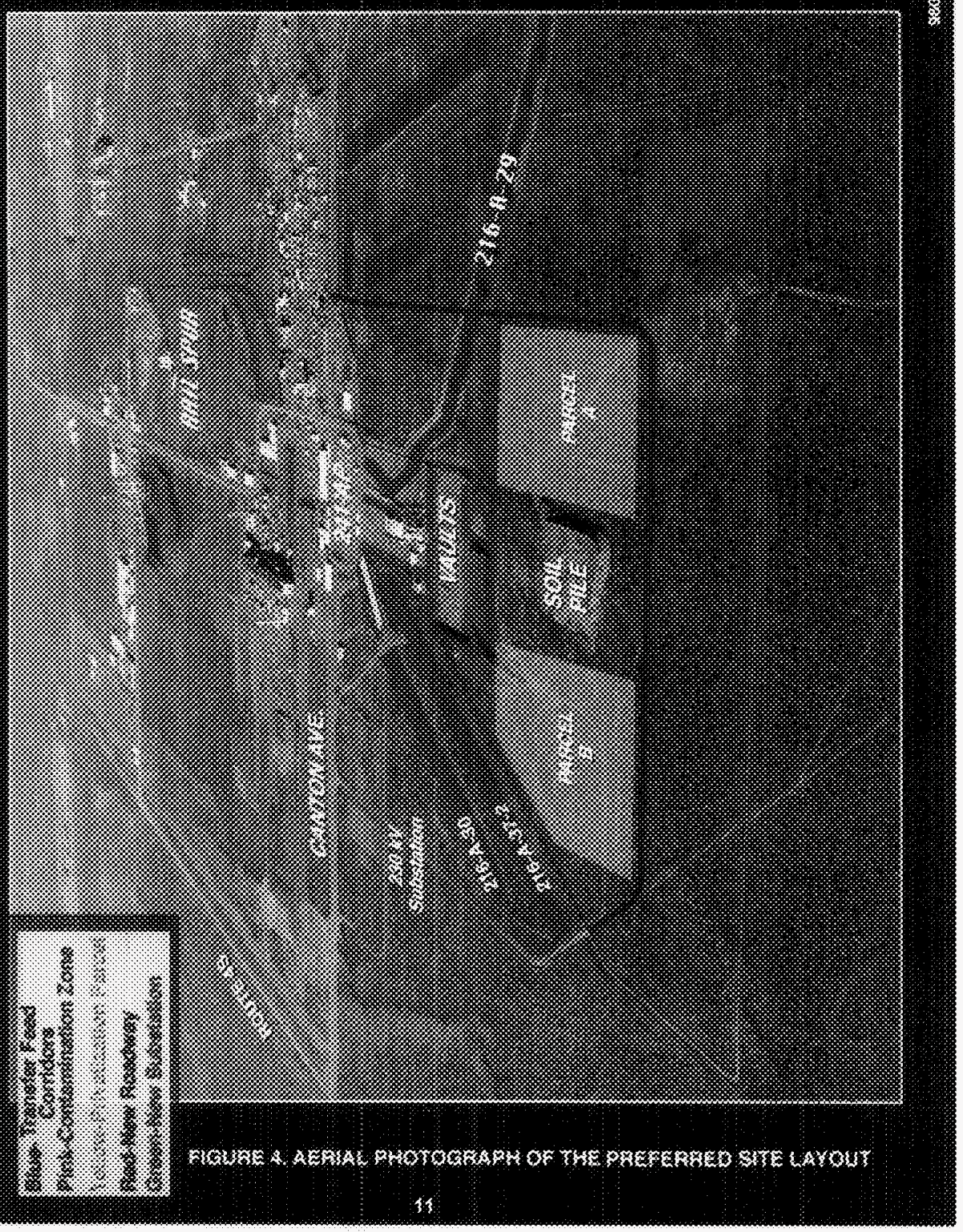




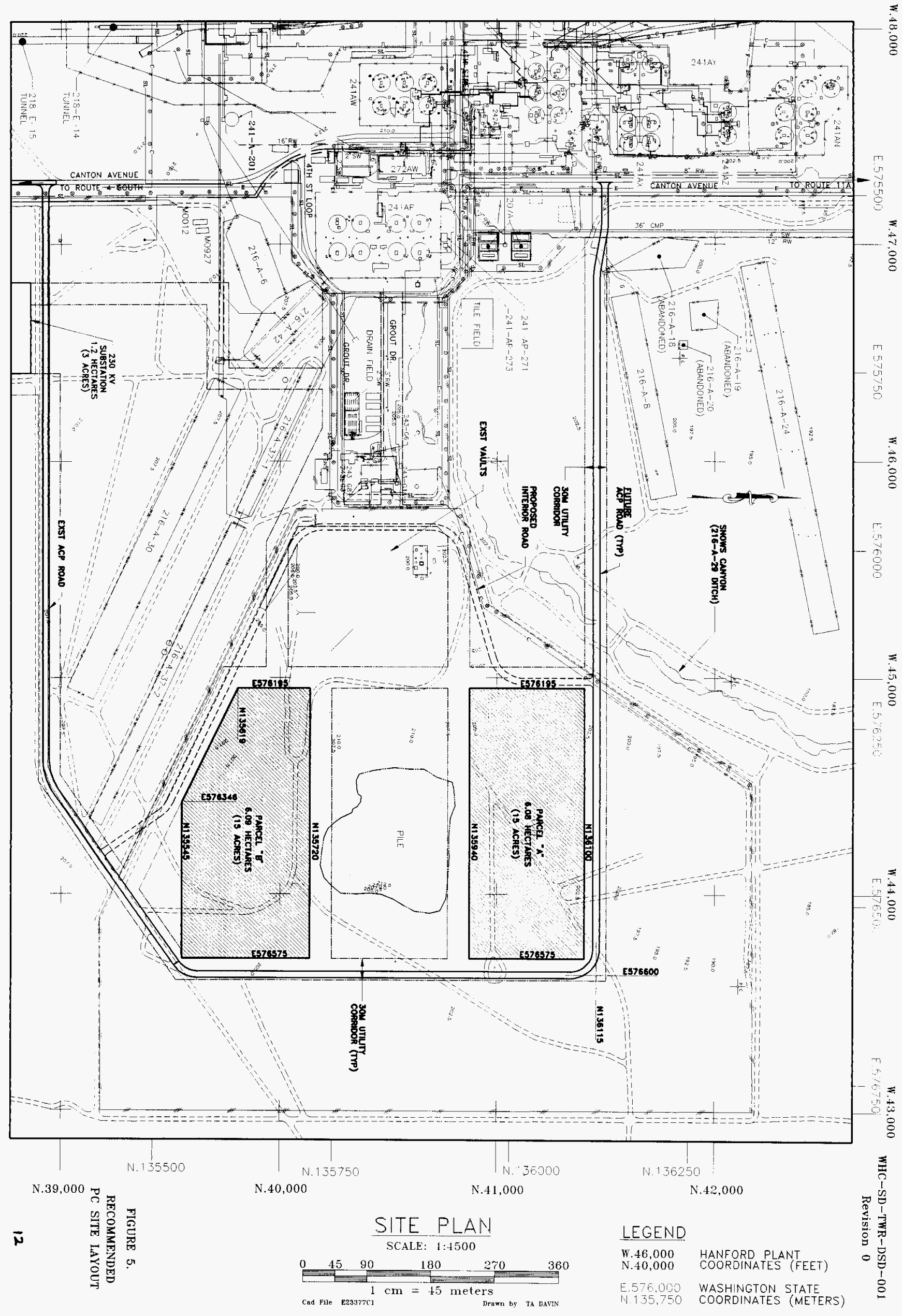


The preferred layout requires the minimum amount of earthwork which results in lower cost to develop. Another advantage of this layout is that it provides a more significant safety buffer zone between the sites. There is a total of 36 ha ( $89 \mathrm{ac}$ ) of usable land for this alternative, of which about 4 ha $(10 \mathrm{ac})$ would be located on embankment fill. If it becomes necessary, the 6 ha. ( 15 acre) sites could be readily expanded into the buffer zone area by removing a portion of or all of the soil mound. Parcel "A" could be expanded to the south and Parcel "B" could be expanded to the north (Fort, 1996).

\subsubsection{Parcel Size}

The preliminary land area requirement evaluation indicates that each PC site needs to be at least 4 ha $(10 \mathrm{ac})$ in size. This amount of land appears to be reasonable when compared to similar projects/examples; however, additional land will be required for items such as:

- $\quad$ Access roads and utility corridors.

- Contractor support facilities and construction worker parking.

- Construction laydown areas.

- $\quad$ Land requirements that have not been identified at this time.

Two separate sites or parcels of 6 ha (15 acres) each are to be developed (Shord, 1996). Features of each parcel are to be as equal as is feasible. Neither parcel shall provide one PC a major advantage.

Past experience has shown that land requirements increase as a project develops and as additional requirements are identified. It is recommended that additional land be reserved to allow for future expansion flexibility to accommodate unidentified future land area requirements.

\subsubsection{Parcel Orientation}

The prevailing wind at this site location is from the northwest and the strongest winds are out of the southwest; therefore, an east-west direction is the most favorable orientation for the buffer zone between the PC sites. This orientation will minimize the possibility of one site being located down-wind from the other.

\subsubsection{Uncertainties}

It is uncertain as to what will be the final layout of the PC parcels. Land requirements of each PC will be established over the next few years, and final size and orientation may differ from the basis or assumptions used. The alternatives were developed based on the PC parcel size and orientations given in previous studies (Trost, 1996). 
Variations and combinations of several of the alternatives evaluated should be reevaluated when more information on the development of each privatization site becomes available.

It is uncertain as to the amount of contamination that will be encountered in traversing an excavation around AP Tank Farm and the existing basins, cribs, waste drain lines, process pipelines, etc. No allowances were applied to the estimates where the potential of discovering contaminated soil exists. It is also uncertain as to whether or not the level of contamination encountered may force some redesign.

The acceptance of a 216-A-29 Ditch crossing by the regulators is uncertain. Only very recently have discussions concerning the issue been held with representatives of the Washington State Department of Ecology. The state representatives have shown a willingness to accept a crossing and have voiced preferences as to the type employed, namely the use of an existing embankment. Additionally, the state may request that some level of characterization be performed in the immediate vicinity of the crossing, especially if any broadening of an existing embankment, or the installation of a new one, is done as part of the effort to install the new pipelines. It is uncertain what level of contamination may be found in the vicinity and the responses the regulators may require to continue using the crossing should contaminant levels exceed expectations.

\subsection{ACCESS ROADS AND RAILROAD}

TWRS PC construction and operations are expected to generate additional traffic to the eastern portion of the 200 East Area, including heavy trucks hauling construction materials. It is anticipated that about 450 vehicles a day will need access to the site.

\subsubsection{Road Access from the South}

The main road access to the site is from the south. The preferred access roads are two-

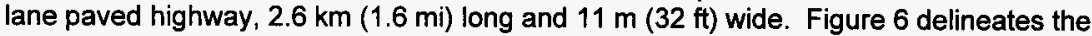
recommended access roads to the site. The preferred alternative utilizes existing roads to reach the site (Ackerman, 1996). The plan is to improve the existing Canton Avenue/Route $4 S$ Intersection to allow for both access and egress movements. A deceleration and right turn lane was constructed in 1994 as part of the Route $4 \mathrm{~S}$ traffic safety improvement effort. About 200 vehicles are presently using Canton Avenue to reach the PUREX and Tank Farm areas in the morning. This intersection can not be used for egress onto Route $4 S$ without providing an acceleration lane to allow exiting traffic to merge with Route $4 \mathrm{~S}$ traffic. As a minimum, this intersection would require a

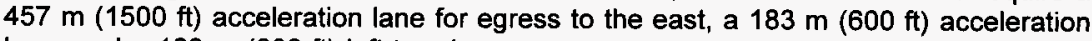
lane, and a $183 \mathrm{~m} \mathrm{(600} \mathrm{ft)} \mathrm{left} \mathrm{turn} \mathrm{lane.}$

The existing east-west access road located on the south side of the 216-A-30 Crib needs to widened from $6.1 \mathrm{~m}(20 \mathrm{ft})$ to $9.8 \mathrm{~m}(32 \mathrm{ft})$. This road provides access to the southeast corner of the most southern parcel (Parcel "B"). A small portion of the 200 

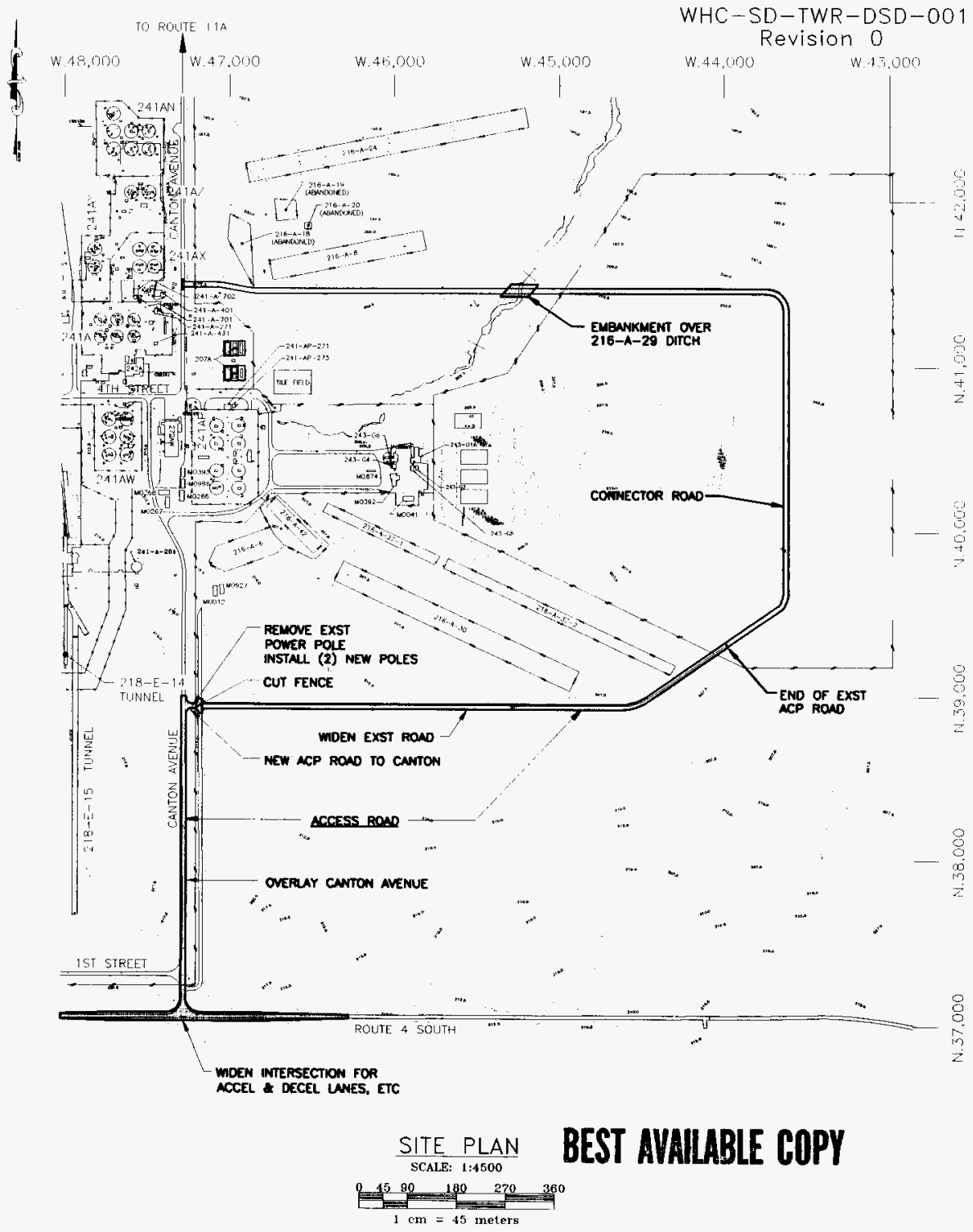

FIGURE 6 .

PREFERRED ACCESS ROAD LOCATIONS 
East Area perimeter fence will have to be removed to connect the road to Canton Avenue. An electrical power pole would also have to be removed and two new poles installed. Other recommended work scope would include applying an asphalt overlay on Canton Avenue. Since traffic on the existing roads is expected to change substantially, and the preferred alternative proposes the extension of new roadways in addition to the upgrading existing roads for a new facility, it is expected that an environmental assessment (EA) will be required in order to meet NEPA requirements. There shouldn't be any radioactive contamination concerns for this alternative. The preferred route will also improve access and egress at the Route 4S/Canton Avenue Intersection for about 200 workers residing in and around PUREX and the tank farms.

\subsubsection{Road Access from the North}

Road access from the north would be provided by a new route that connects with Canton Avenue northeast of the 242-A Evaporator, proceeds eastward across Snows Canyon on a new fill to the north boundary of the most northern parcel (Parcel A). This alternative was selected (Ackerman, 1996) as the best alternative for the following reasons:

- It is the most direct route and does not cross internal roads where movement of product canisters would impede traffic flow periodically as with the other alternatives.

- The route does not cross AP Tank Farm Transfer/Feed lines to Parcel "A".

- The route provides a clean fill above the potentially contaminated soils in Snows Canyon for placing of utility lines.

\subsubsection{Railroad Access}

Identifying a good railroad access route to the site was not easy. Should rail service into the TPPI site be required, the only practical route that was found (Ackerman, 1996) that meets both the vertical and horizontal alignment criteria is shown in Figure 7 . The new railroad spur would tie to the rail spur located south of the 200 East Area Steam Plant. The new spur would then proceed southeast around the south end of the PUREX tunnel and then northeast to the south boundary of the site.

If direct railroad access is not required, an existing siding located within the 200 East Area could be used for unloading equipment and materials for both construction and operations. The recommended siding is also shown in Figure 7. This railroad spur, located north of 4th Street, that served for unloading of grout materials, could be used until TWRS Phase II construction work commences. It presently appears that the rail spur will have to be removed to make room for the TWRS Phase II processing facilities. A new siding would have to be identified or constructed at that time. 


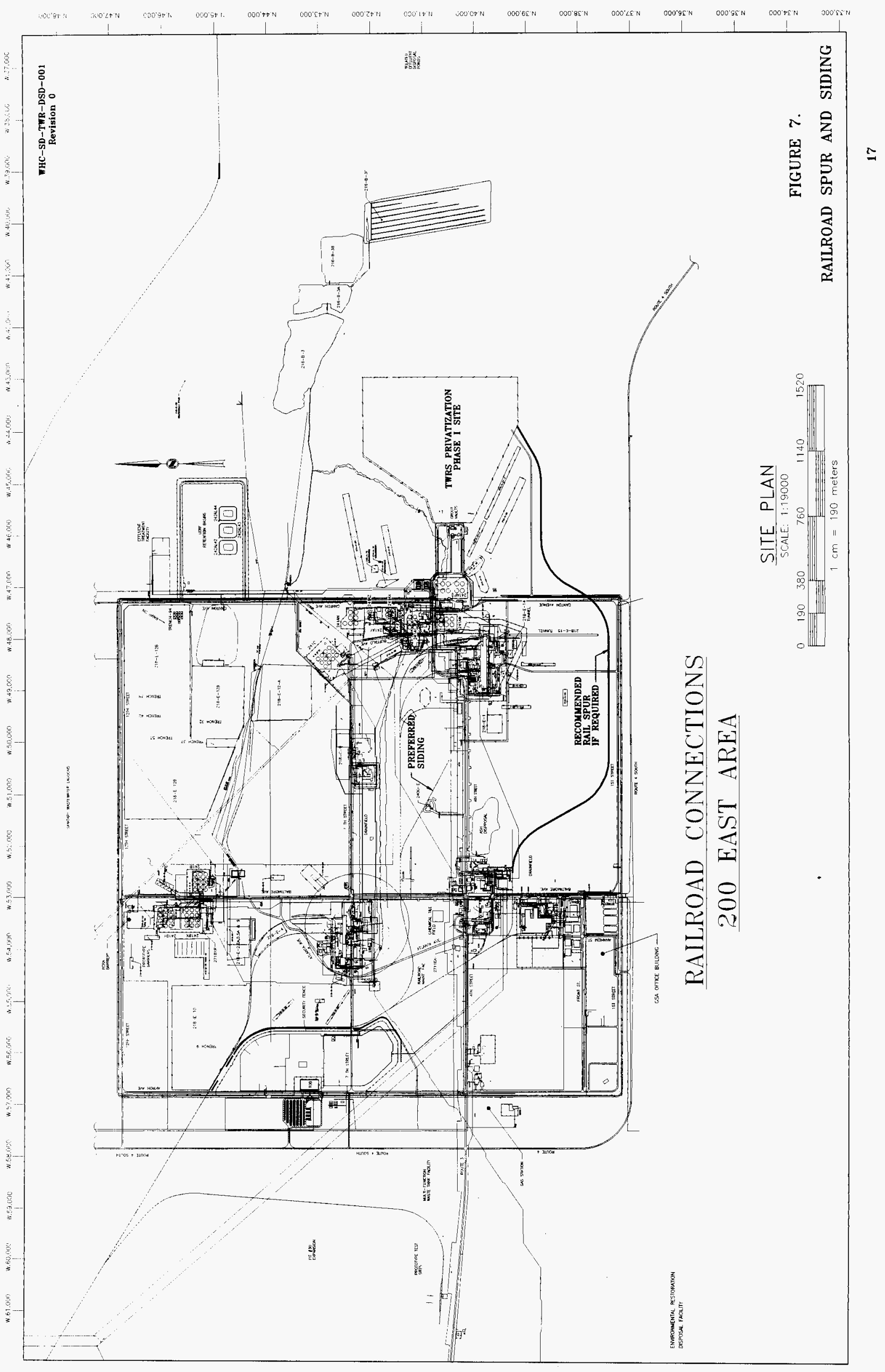




\subsection{MONITOR WELL COORDINATION}

Three Groundwater Programs rely on wells within the area to meet Federal, state, or U.S. Department of Energy (DOE), Richland Operations Office (RL) groundwater compliance requirements; Westinghouse Hanford Company (WHC) RCRA and Operational Monitoring (ROM), Pacific Northwest National Laboratory (PNNL) Sitewide Surveillance, Bechtel Hanford Inc. (BHI) Comprehensive Environmental, Response, Compensation, and Liability Act of 1980 (CERCLA), (Williams, 1996).

There are a total of 21 wells within the demonstration area, 10 fulfill RCRA, CERCLA, or Sitewide groundwater program compliance requirements and DQOs (well 299-E25-25 will require surface remediation [or a state variance] to bring it into compliance with the WAC regulations). Six wells have, previous to this study, been decommissioned, and four wells have been identified to be decommissioned per the decommissioning plan (Skoglie 1996). One additional well, 299-E25-29, will be decommissioned as it becomes too difficult to sample.

New well requirements within the demonstration area include; one new characterization well installed in support of the ILLW Storage Facility and as will be determined a possible replacement well for 299-E25-32. Any additional RCRA groundwater monitoring requirements at the ILL facility will be addressed separately in the appropriate RCRA groundwater monitoring plan as required by the facility permit. The PC(s) will have the opportunity to procure any of the targeted category 2 wells prior to decommissioning.

\subsubsection{Wells Compromised by PC Construction Activities}

Results of the evaluation of the category 4 wells, completed by the three groundwater programs (RCRA, CERCLA, and Sitewide), are described in this section. Based on a review of the PC site boundaries, only one well (Well 299-E25-32) falls within the boundary of Parcel "A", see Figure 8 . Three other category 4 wells that are located near the PC sites (299-E25-25, -39, and -1000) have been prioritized according to the existing program(s) importance, i.e., based on program DQOs, spacial location, and the remaining saturated interval within the wells. Based on this prioritization the need for, and replacement of, the impacted wells can be defined. 


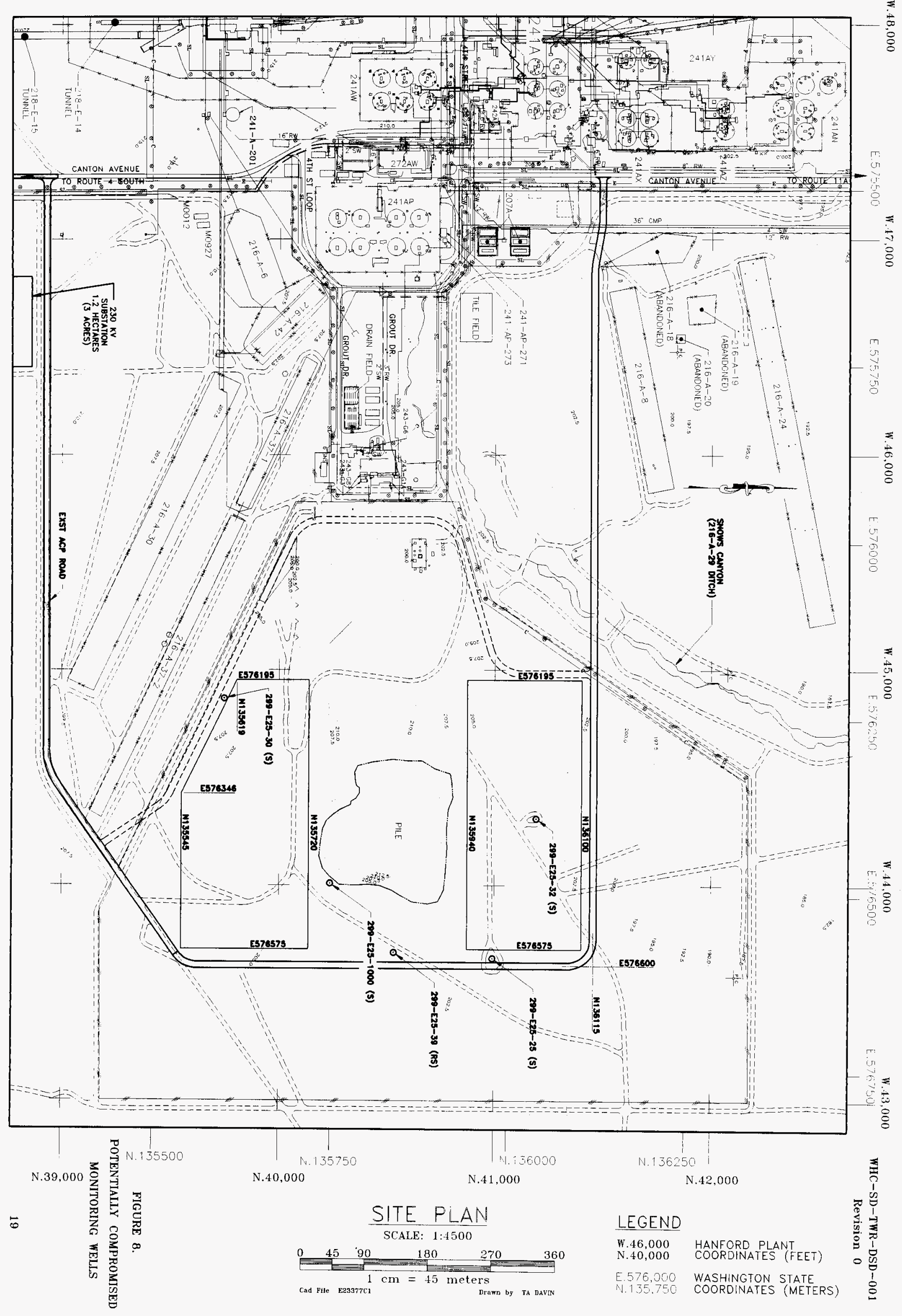


The potentially compromised category 4 wells are prioritized as follows:

- $\quad$ Priority 1 - Well 299-E25-32 - Groundwater results support all three programs (RCRA, CERCLA, Sitewide). This well has added value because it is completed in two intervals (piezometer) within the upper aquifer and thus provides information about the vertical gradients, and radiochemical distribution across the interval. It is one of only a handful of wells at Hanford which provide this type of access to the aquifer. The location of this well is key to understanding the impacts and effects of B-Pond recharge to the aquifer, the decline of the artificial groundwater mound, and changes to the flow system. RCRA utilizes this well as an upgradient location for several facilities. This well also has a good historical groundwater database and declining groundwater will not impact the ability to sample this well.

- Priority 2 - Well 299-E25-25 - Utilized by the PNNL Sitewide Surveillance program. This well's location is also key to tracking the B-Pond mound decline and changing groundwater conditions. Declining groundwater will not impact the ability to sample this well.

Well 299-E25-1000 - Utilized by the PNNL program. This is the newest of all the wells within the area and is in a location that supports the evaluation and interpretation of regional groundwater conditions. Declining groundwater will not impact the ability to sample this well.

- Priority 3 - Well 299-E25-39 - Utilized by the PNNL program. This well is also in a good location for evaluating the B-pond mound decline and effects on regional groundwater conditions. Declining groundwater will impact the ability to sample this well. Less than $8 \mathrm{ft}$ of water is left in the screen and projected declines indicate that this well will go dry in a few years.

The Priority 1 well, E25-32, will require a replacement well installed further east if the $\mathrm{PC}(\mathrm{s})$ construction activity requires this well be decommissioned. Priority 2 wells will require one replacement if $299-E 25-1000$ or both wells are decommissioned. Or well 299-E25-1000 maybe substituted for 299-E25-25 if it is decommissioned. The Priority 3 well can be decommissioned if necessary or it will be systematically decommissioned when it can no longer be sampled.

Only one category 4 well (299-E25-32) will likely be impacted. Based on the Priority 1 classification this well will require a replacement installed if it must be decommissioned. The other four potentially compromised wells are located far enough east of the proposed construction zones that they currently pose no problem. Easements can be placed around these wells to maintain access for sampling and provide protection from future land-use activities. 
One category 3 well, 299-E25-30, is potentially impacted as it lies near the southwest corner of "Parcel B". Similar to the category 4 wells, an easement can be placed around this well to maintain access for sampling and provide protection from future land-use activities.

\subsubsection{Future Well Access}

After the initial facility construction all planned construction activities shall be engineered to allow continued access to the active wells, for the purpose of program groundwater sampling, well maintenance, or other scheduled work. Any contractor wishing to access wells will be required to acquire approval from the well custodian.

\subsection{LOW-LEVEL WASTE INTERIM STORAGE COORDINATION}

It is being proposed to use the existing four grout vaults as temporary storage facilities for the immobilized low-level waste (Burbank, 1996, and Calmus, 1996). Other storage facilities will be constructed on the TWRS Privatization Phase II Facility site which is located in the center of the 200 East Area.

\subsection{WATER DISTRIBUTION SYSTEM}

To prepare for the $\mathrm{PC}(\mathrm{s})$ development of their assigned sites, utilities must be extended from the 200-East Area infrastructure. Pertinent issues relating to the extension of raw, fire suppression, and sanitary (potable) water services to the boundary of the parcel to be assigned to each PC have been addressed (Fort, 1996).

The extension of the existing 200-East Area water distribution system is the only viable means of providing raw, fire suppression, and potable water service to the privatization site. The existing infrastructure has the reserve capacity to provide the quantities of water required by the two privatization contractors. The means by which the existing distribution system should be extended is by the installation of a raw water loop extension and a sanitary water pipeline extension as shown in Figure 9.

The 24-hour averaged flow requirements for process (or raw) water, fire suppression water, and potable (or sanitary) water were provided through an informal direction from the TWRS Privatization Source Evaluation Board during contract negotiations with prospective $\mathrm{PC}(\mathrm{s})$.

The preferred alternative utilizes an abandoned water line as an encasement to reduce the amount of excavation through congested areas. Though the existing line has a good chance of providing the service proposed, there are uncertainties as to the condition of the pipeline. The implementation of the preferred alternative will have minimal impact in the day to day operations of the existing 200-East Area infrastructure. System demands will remain below maximum capacity. Various maintenance activities would be expanded, but it is anticipated they would have minimal impact on the current operations. 


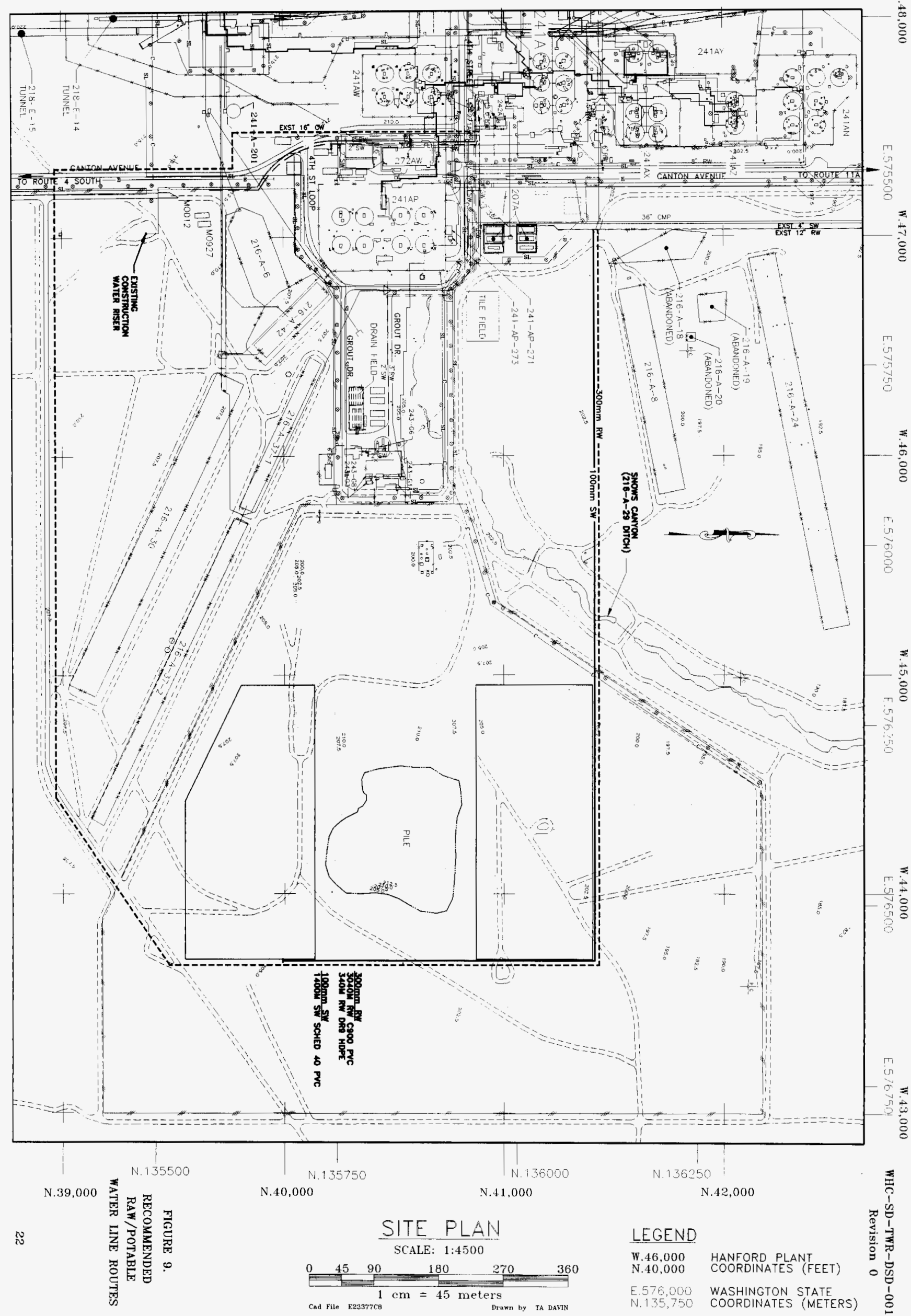




\subsection{ELECTRICAL DISTRIBUTION SYSTEM}

A new substation will be required to provide electrical power to TWRS Phase I (Singh, 1996). The site tentatively selected for the substation was previously disturbed and has not been reserved for any other project or proposed use. The location of the substation and the preferred route for the two $230 \mathrm{Kv}$ transmission lines which will connect to the $230 \mathrm{Kv}$ line located north of Route 11A is shown in Figure 10. The preferred route starts at the new substation and proceeds to the east for $2430 \mathrm{~m} \mathrm{(8000} \mathrm{ft.);} \mathrm{the} \mathrm{route} \mathrm{then}$ turns 90 degrees to the north for $3660 \mathrm{~m}$ (12000 ft.). Another potential route to the east and then to the north which is $1220 \mathrm{~m}$ (4000 ft.) shorter was identified, but would require the spanning of "B" Pond and working in potentially contaminated areas. This alternative could be evaluated in the future for potential cost savings.

As the substation site is located between TWRS Phase I and Phase II facilities, the substation can be expanded to meet a portion of the TWRS Phase II requirements.

\subsection{EFFLUENT COLLECTION AND DISPOSAL SYSTEM}

The Effluent Collection and Disposal Engineering Study identified applicable constraints, resolves outstanding issues, and established performance requirements required to optimize the overall effluent transfer system performance (Palit,1996). Two separate pipelines will be provided: a radioactive/dangerous system route, see Figure 11 and a non-radioactive/non-dangerous system route, see Figure 12.

\subsubsection{Conclusions}

The most suitable options are summarized as follows:

- Install underground piping southwest of the grout area as detailed in alternative 2 of this study for high volume of effluent generation.

- Use of a $18925 \mathrm{~L}$ (5000 gallon) tank trailer for effluent generation rates below 3.79 Liters/min (1 gpm). Skyrocketing operating cost makes this option not cost effective for effluent generation above $3.79 \mathrm{Liters} / \mathrm{min}(1 \mathrm{gpm})$.

\subsubsection{Externally Imposed Constraints}

Constraints are requirements that are imposed by external organizations and are typically non-negotiable. The design, installation, operation and maintenance of the liquid effluent transfer system are affected by many state and federal regulations, agreement, and Westinghouse requirements. There are many guidelines and specifications which set forth engineering requirements deemed necessary for safe design and construction of the liquid effluent system in addition to these requirements. The requirements and guidelines presented in these regulations, Orders, and agreements must be followed when designing a new liquid effluent transfer system. 


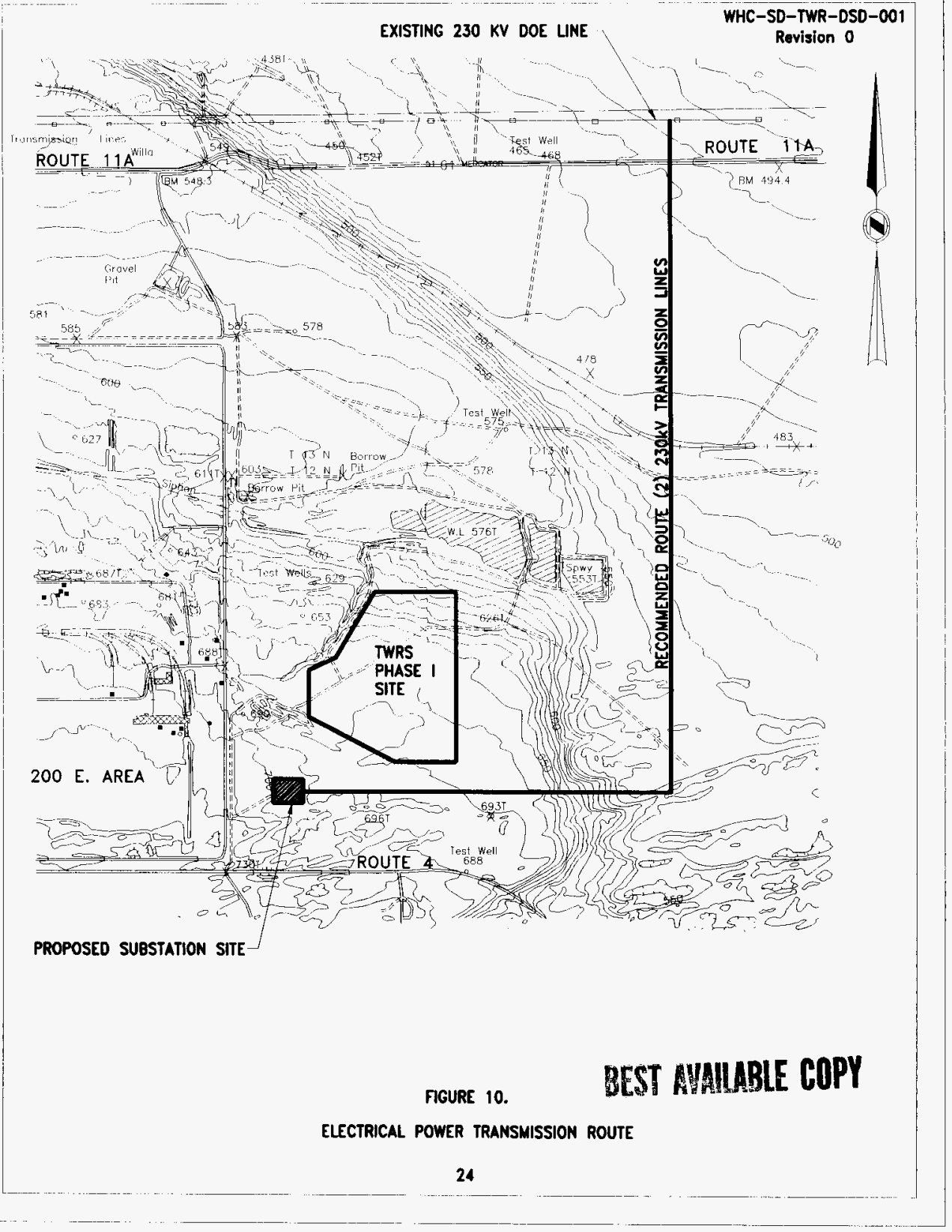




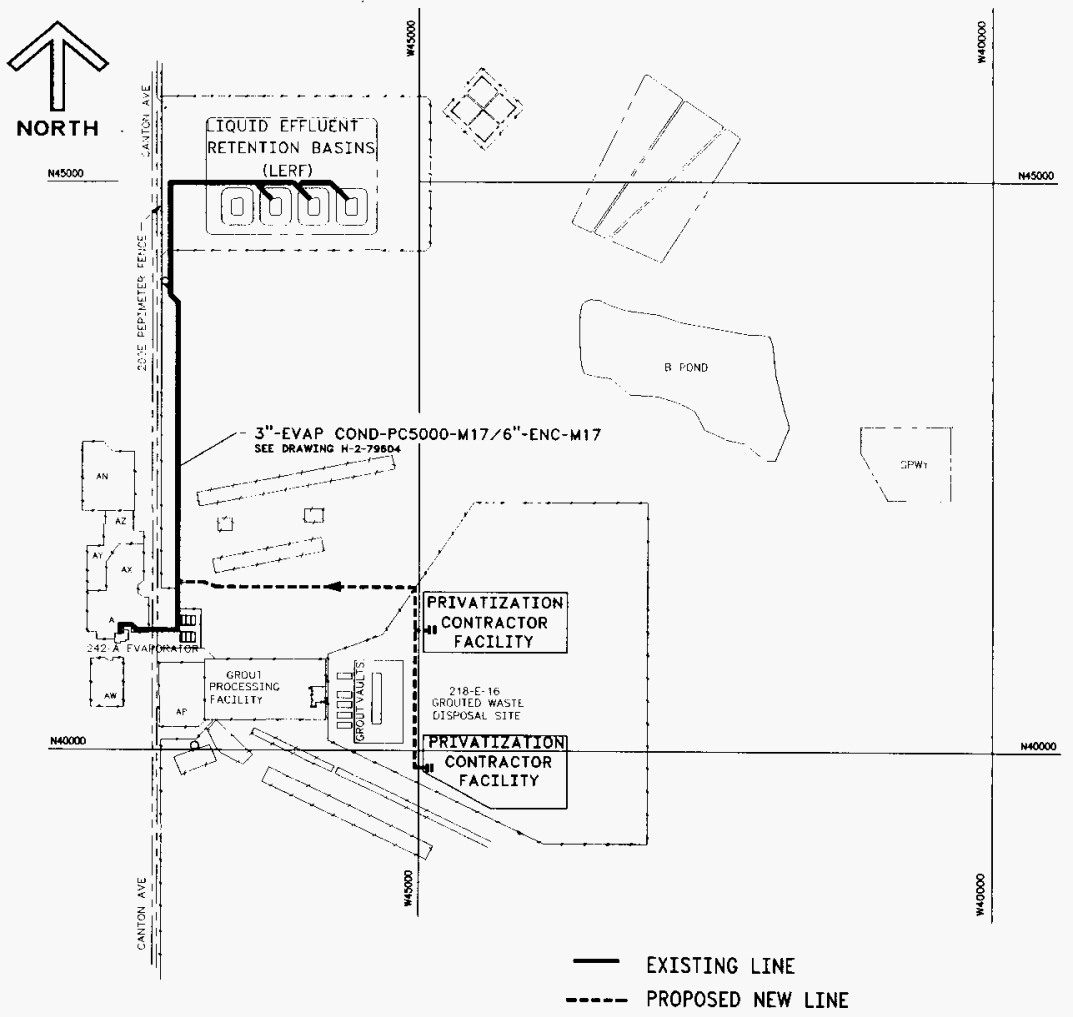

FIGURE 11

RADIOACTIVE, DANGEROUS

LIQUID EFFLUENT TRANSFER SYSTEM 


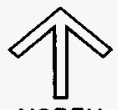

NORTH

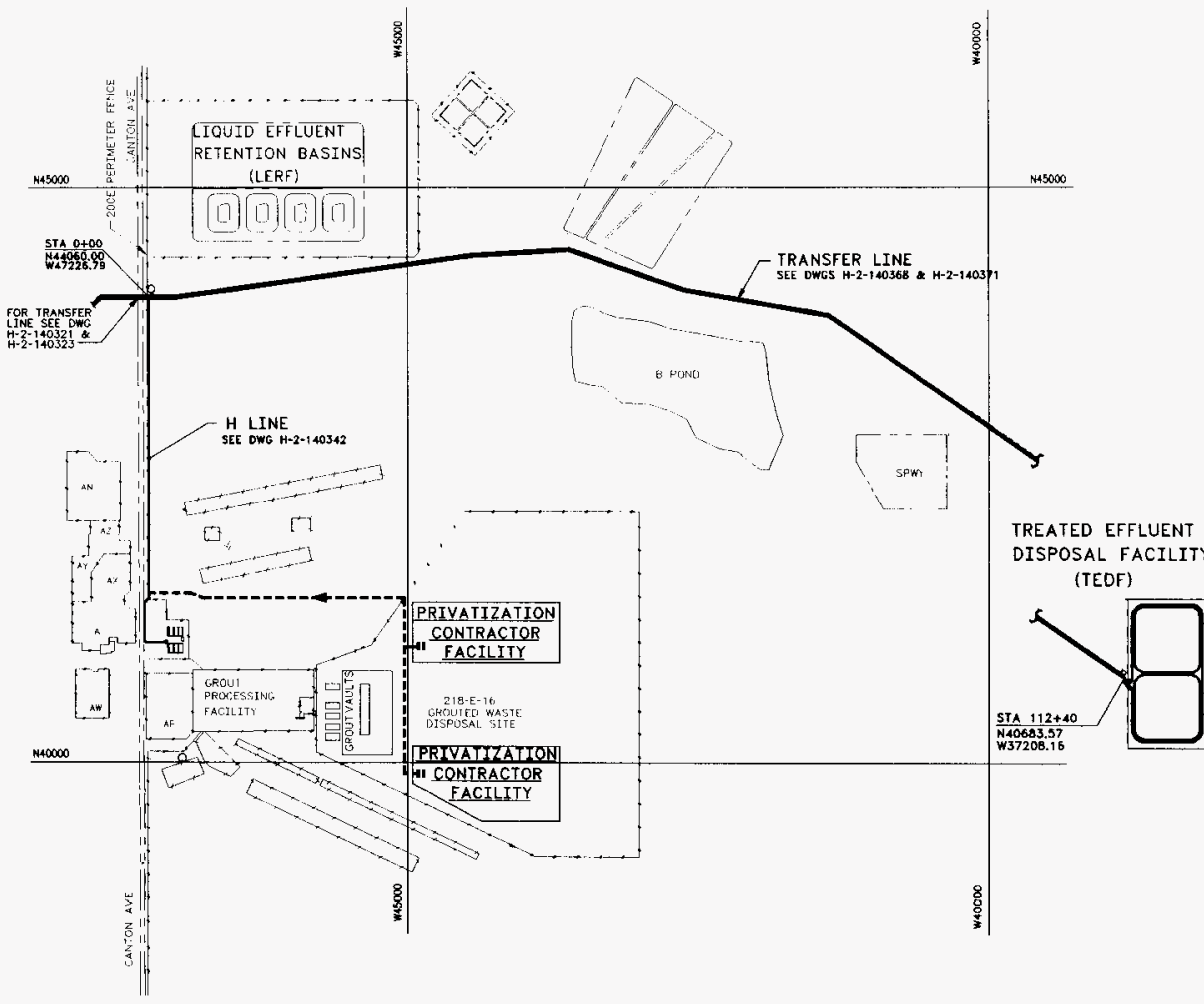

- EXISTING LINE

PROPOSED NEW LINE

BEST AFALABIE COPY

FIGURE 12

NON-RADIOACTIVE, NON-DANGEROUS

LIQUID EFFLUENT TRANSFER SYSTEM 
The format below establishes a hierarchy into the listed documents to be used during definitive design stage of the liquid effluent transfer system:

DOE Order $6430.1 A$
DOE Order $5820.2 A$
WAC 173-303
WHC-IP-1043
WHC-SD-G-DGS-30011
WHC-CM-4-46
WHC-SD-GN-DGS-30008

General Design Criteria. Radioactive Waste Management. Dangerous Waste Regulations. WHC Occupational ALARA Program. Radiological Design Guide. Non-Reactor facility Safety Manual Design Loads for New Underground DSTs and Associated Underground Process Piping.

\subsubsection{Treatment Facility Influent Restrictions}

Treated Effluent Disposal Facility (TEDF)

The non-radioactive, non-dangerous liquid effluents will be discharged into the Treated Effluent Disposal Facility (TEDF) which does not have any treatment or retention capacity. Strict control at the generating facility interface is therefore essential to operate the TEDF in compliance with the requirements of the following documents:

$\begin{array}{ll}\text { DOE/RL, Order 5400.xy } & \begin{array}{l}\text { Radiation Effluent Monitoring and Environmental } \\ \text { Surveillance }\end{array} \\ \text { DOE/RL, Order 5400.1 } & \begin{array}{l}\text { General Environmental Protection Program } \\ \text { State Waste Discharge Permit Program. }\end{array} \\ \text { WAC 173-216 } & \text { State Waste Discharge Permit } \\ \text { Permit No. ST4502 } & \begin{array}{l}\text { 200 Area Treated effluent disposal Facility Interface } \\ \text { WHC-SD-W049H-ICD-001 }\end{array} \\ & \text { Control Document }\end{array}$

Liquid Effluent Retention Facility (LERF)

The radioactive, dangerous liquid effluent will be discharged into Liquid Effluent Retention Facility (LERF). The LERF is a passive facility which will receive the effluent for temporary storage and subsequent treatment at the Effluent Treatment Facility (ETF). The following documents set guidelines for acceptance of feed streams for treatment at the LERF/ETF complex:

40 CFR 268

WHC-SD-W105-SAR-001

WAC 173-216

DOE/RL-90-43

Permit No. ST4500

60FR31115

WHC-SD-ETF-WAC-001
Land Disposal Restrictions

Liquid Effluent Retention Facility FSAR

State Waste Discharge Permit Program.

LERF Part B Permit Application

State Waste Discharge Permit

EPA Approval of Delisting Petition, DOE/RL-92-72

Acceptance of Feed Streams for Treatment at the LERF/ETF complex. 


\subsection{TRANSFER LINES/FEED LINES}

The $\mathrm{PC}(\mathrm{s})$ will be responsible for selecting the route and installing the transfer/feed lines from the AP Tank Farm to the PC sites. A utility corridor has been established through the northern portion of the former grout processing site with the north boundary being the existing Grout Facility low-level feed line. A southern corridor has been established with the southern boundary being the existing fence line, see Figure 13. There are a number of mobile offices and utilities located in the area. Several may have to be relocated to make sufficient room for the new transfer/feed lines.

\subsection{CONSTRUCTION PHASING}

A drawing showing the location of temporary construction water and power has been included as Figure 14. The corridors for the permanent $13.8 \mathrm{Kv}$ transmission lines are also shown on Figure 14. Construction scheduling will allow for construction activities to be planned and located to reduce excessive land use and circulation conflicts. Infrastructure phasing will allow development of a utility and circulation plan which minimizes cost impacts and duplication, and supports the development schedule of the overall site.

A schedule has been developed that presents the course by which access roads, process water, fire suppression water, potable (sanitary) water, liquid effluent lines, electrical power, etc., can be provided to each PC by May, 2000 (see Figure 15). It should be noted that the schedule takes into account the integration of the construction of the water services with that of the various other utilities and services. As an example, road services are also to be provided to each parcel by 2000 . To avoid excavating into or through previously completed roadways, the construction of the water lines should be completed prior to the need for final grading of the roads. Also, it would be anticipated that the initial clearing and grubbing of water line alignments would occur during the winter of $1998 / 1999$ as part of the site preparation/road construction activities in order to avoid impacting some species that have been nominated for the threatened species list. Performing construction work in the winter results in additional costs; therefore, the decision to treat nominated birds as if they already on the threatened species list should be reconsidered. 


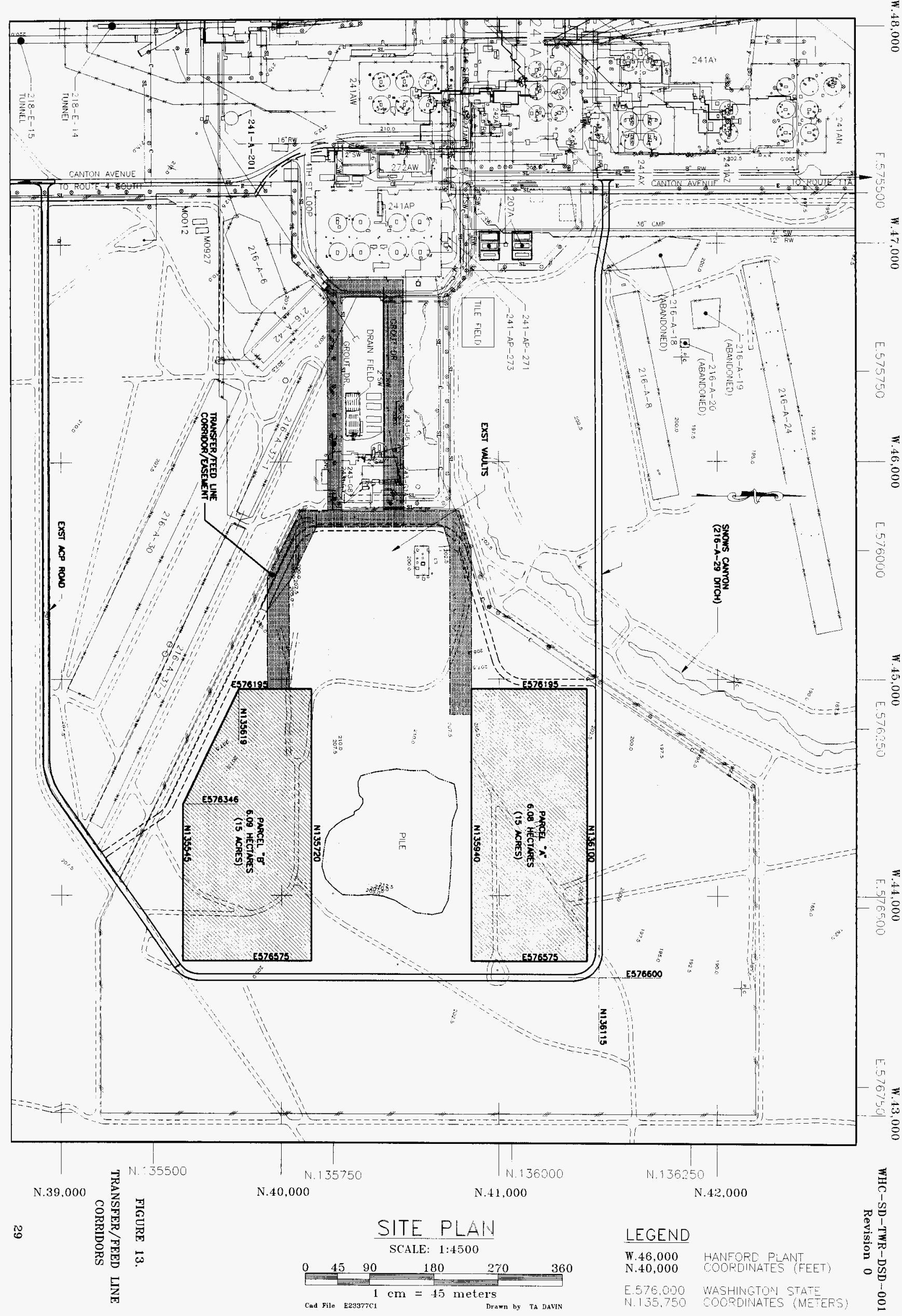




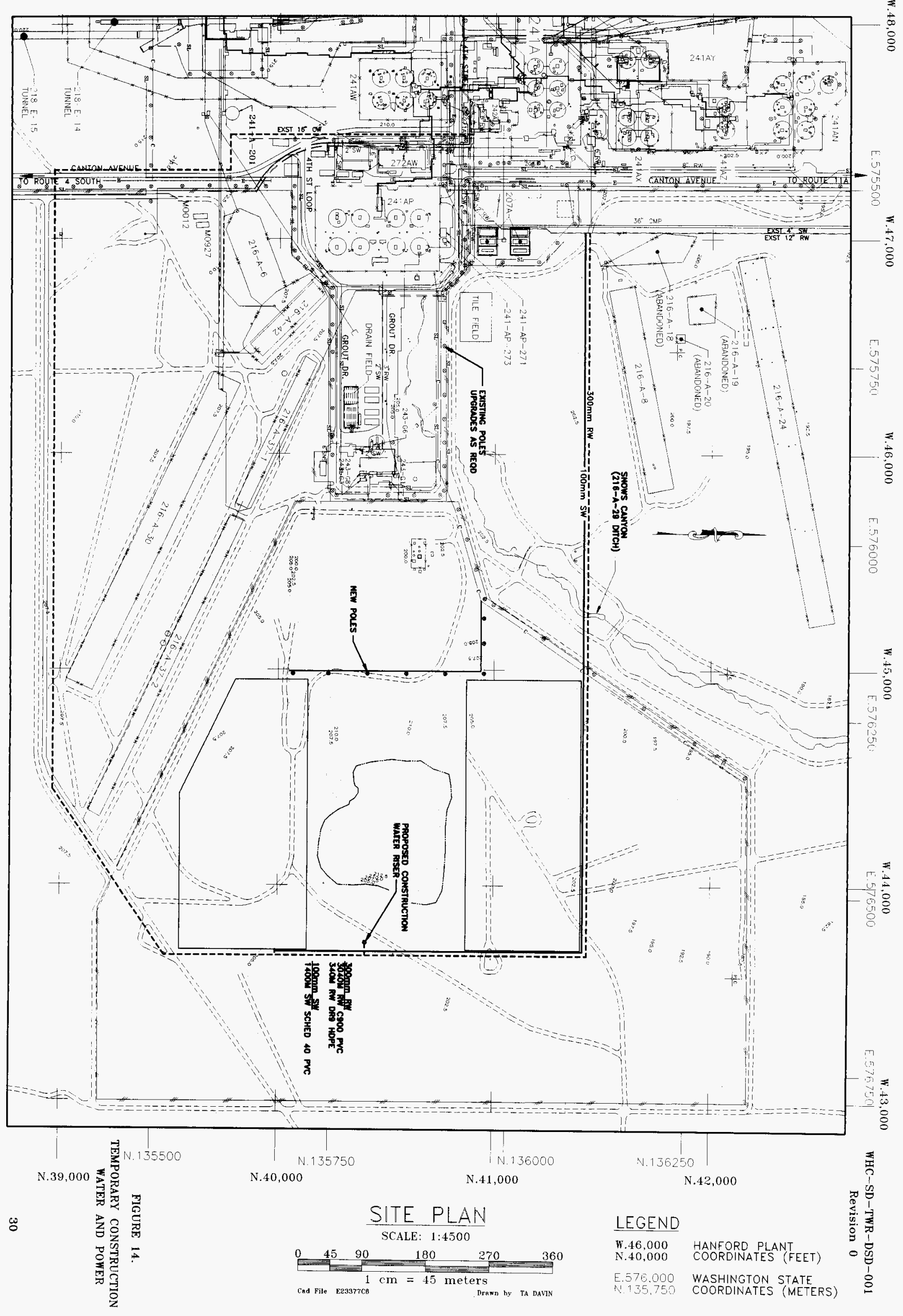




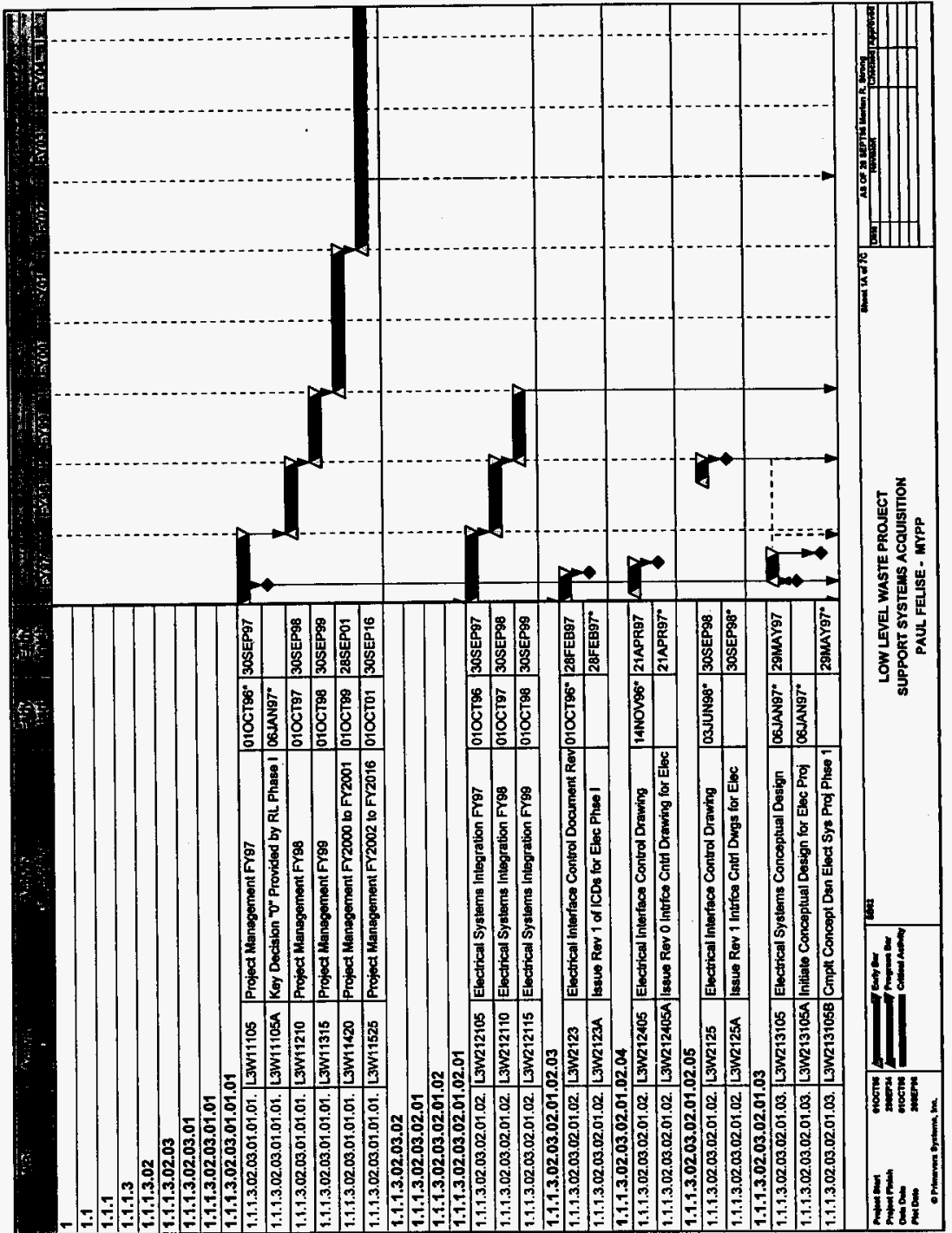

FIGURE 15. SCHEDULE 


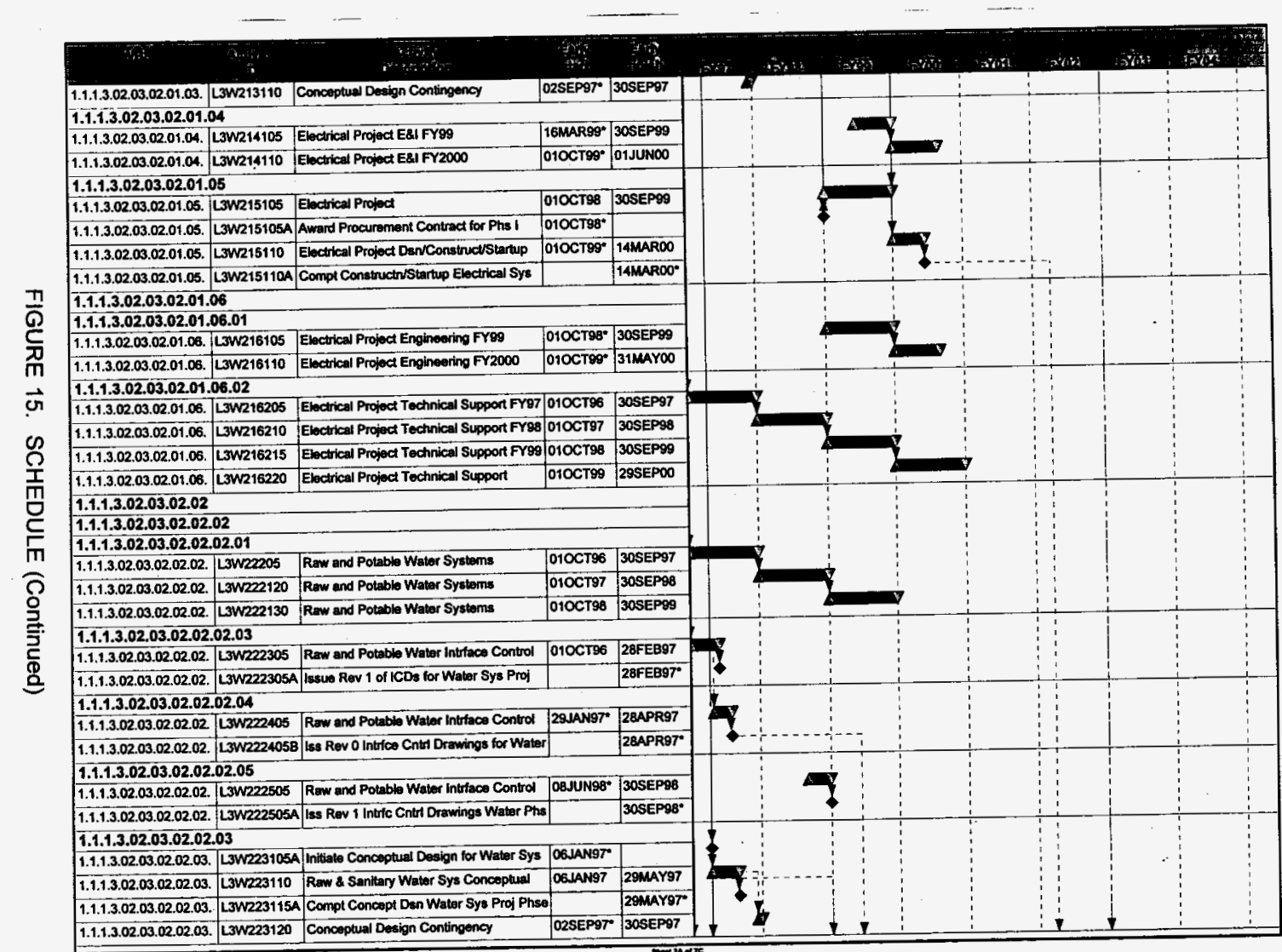




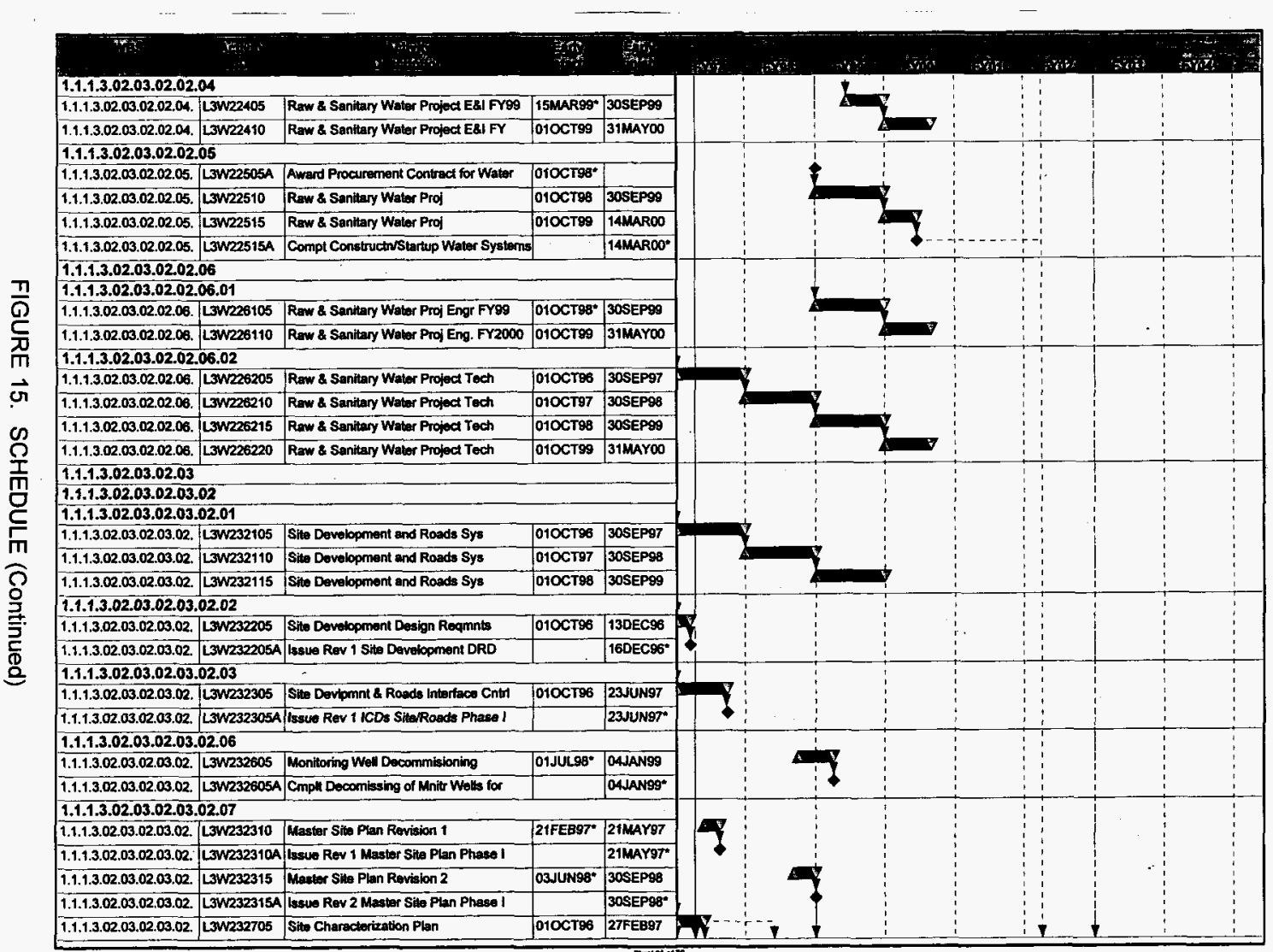




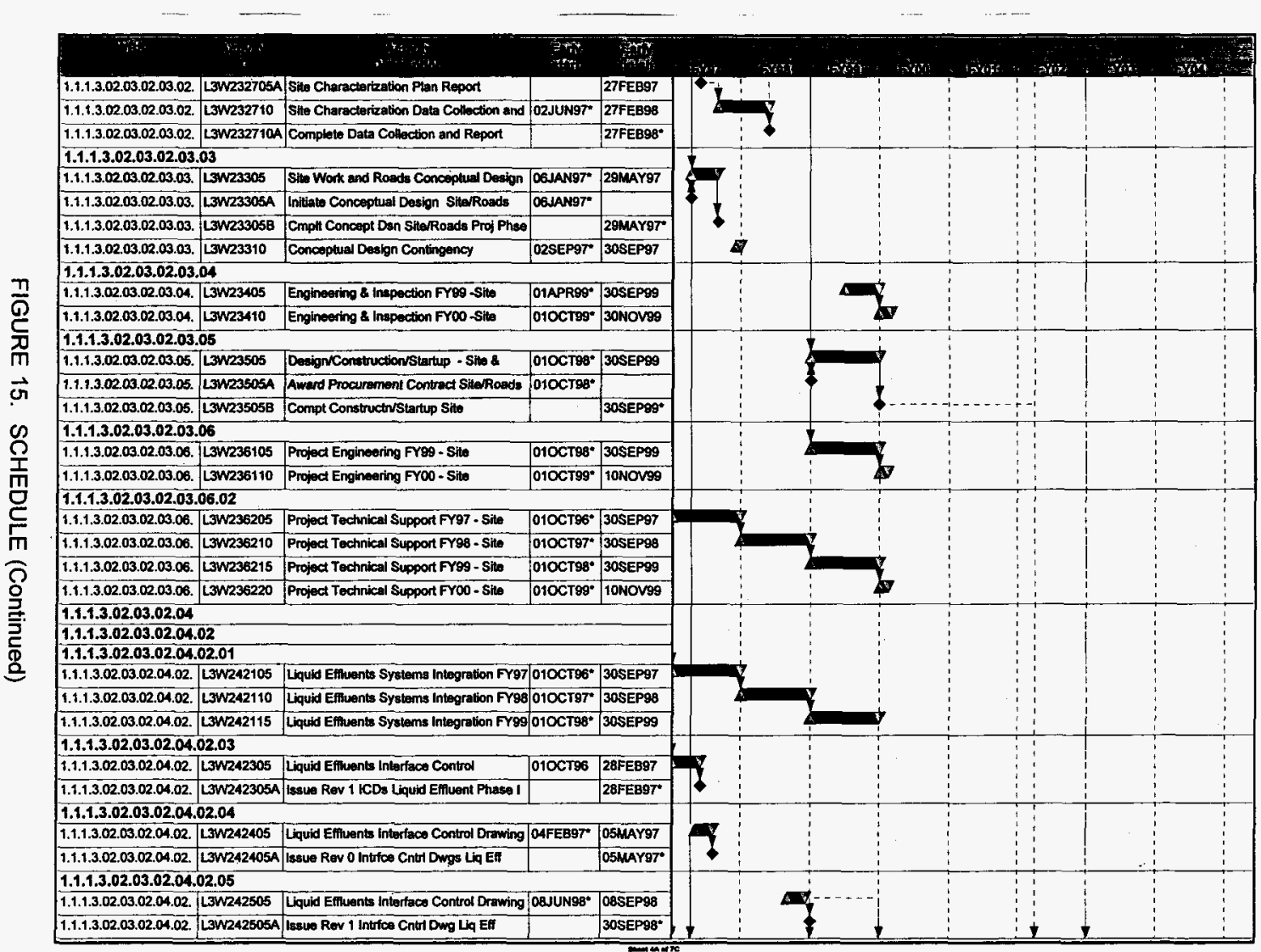




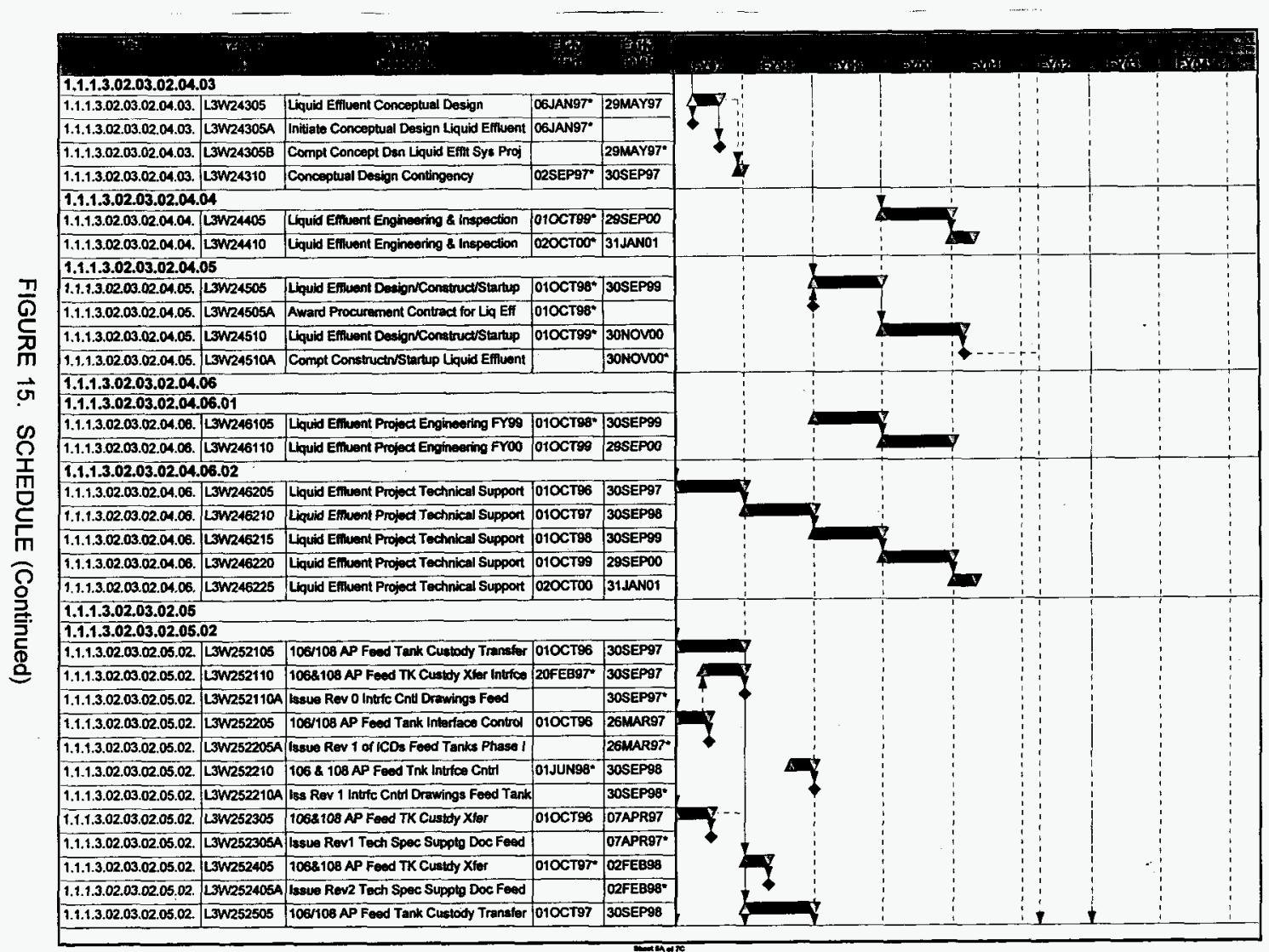




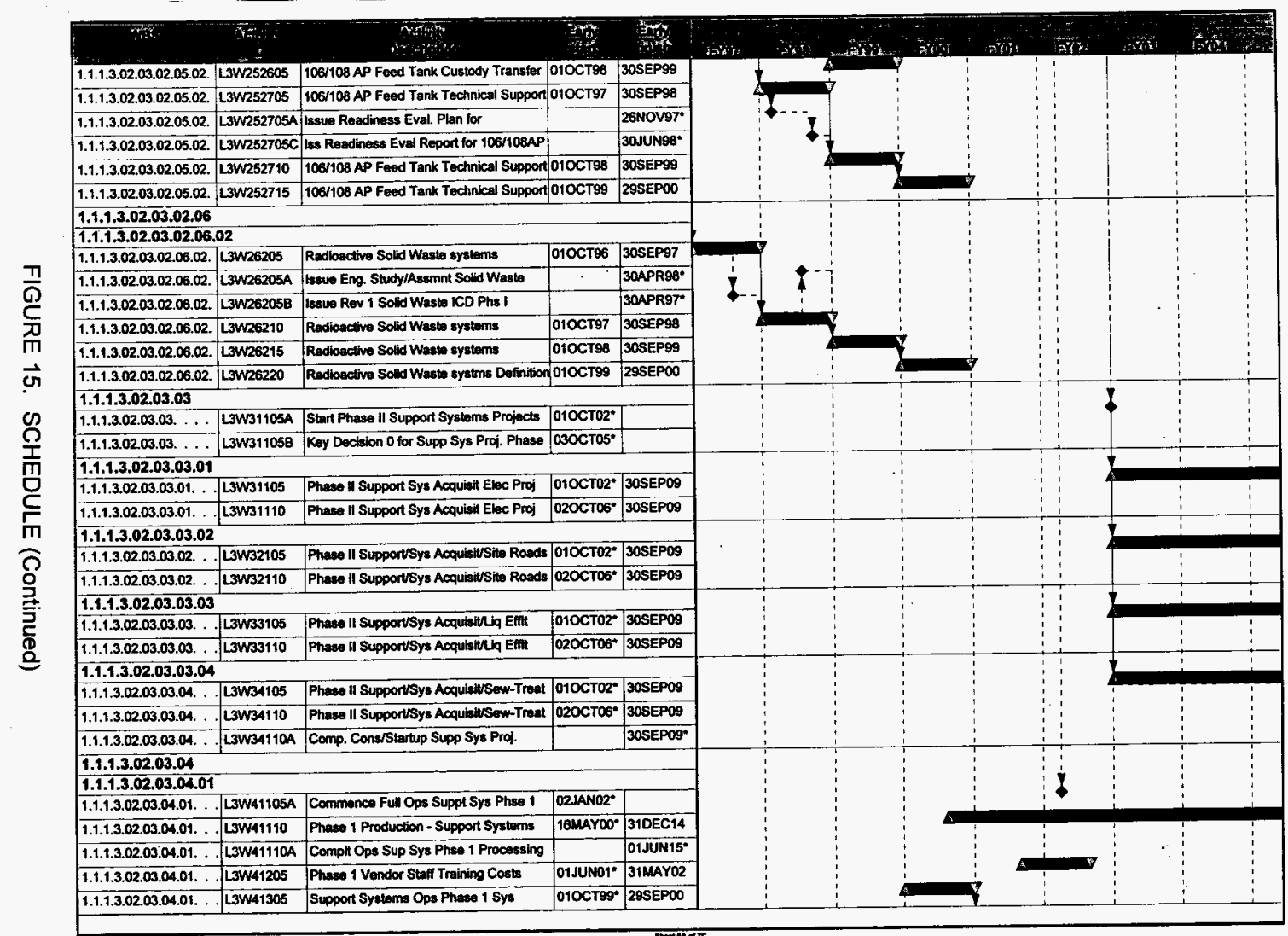




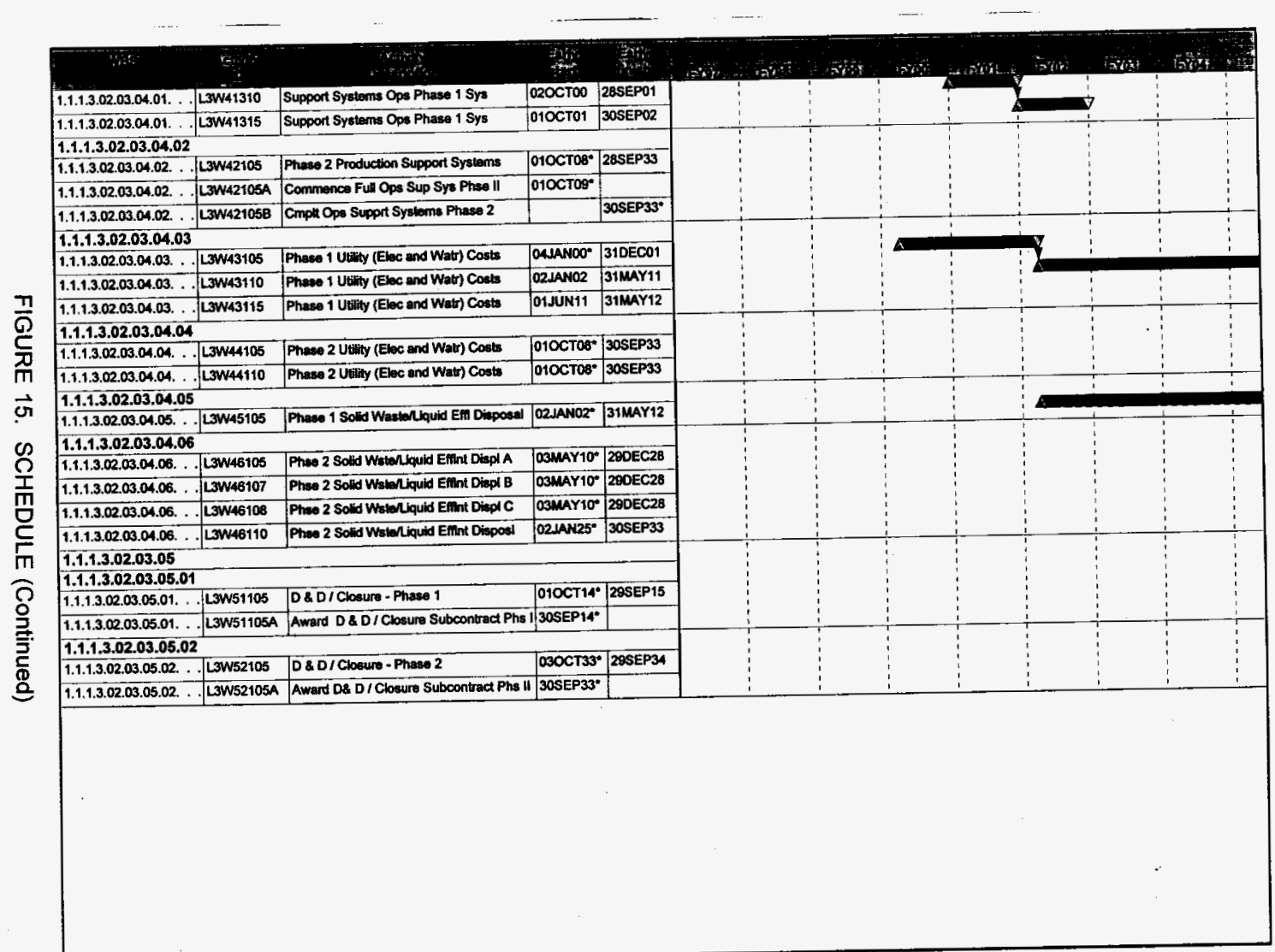




\subsection{CONCLUSIONS AND RECOMMENDATIONS}

It is recommended that DOE/RL prepare the TWRS Phase I Site for the PC(s), via a site preparation construction project. The site preparation project would include, but not necessarily be limited to, the following:

- General site preparation consisting of clearing and grubbing of proposed utility corridors and minor earthwork required, outside of the PC site boundaries, for access roads to the PC sites.

- Railroad service could be provided to the site if determined to be practical; however, it is more likely that the former Grout Materials Siding will be used for materials and equipment delivered by rail cars

- Utility installation, including a looped raw water line, a potable water line, electrical power transmission lines and a new substation, effluent disposal lines and telecommunications to the site boundaries.

A more detailed scope, schedule and cost estimate for this project needs to be defined in the near future, so that the overall TWRS development schedule is not impacted.

\subsection{MASTER SITE PLAN MAINTENANCE}

The Master Site Plan will serve as the single source planning document for the TPPI Site. The MSP will coordinate temporary and permanent land use, utilities, and traffic flow for the overall program. It will identify needs, requirements and conflicts. As such, it not a static, one-time effort. Rather, it is a flexible plan which will be constantly maintained to reflect changes as additional project data or program revisions become known. It is emphasized that future funding should be allocated for the maintenance of the MSP. The Master Site Plan is included as Figure 16.

\subsection{REFERENCES}

Request for Proposals, 1996, (RFP) No. DE-RP06-96RL13308, U.S. Department of Energy, Richland Operations Office, Richland, Washington.

Alm, A. L., June 10, 1996, Integrated strategic planning, budgeting, and management system/10 year planning, Draft Guidance for the 10-Year Plan, Assistant Secretary for Environmental Management, Department of Energy, Washington D.C. 
Shord, A. L., 1996, Tank Waste Remediation System Privatization Phase I Site Evaluation Report, WHC-SD-WM-SE-023, Westinghouse Hanford Company, Richland, Washington.

Muther, R., 1987, Systematic Planning of Industrial Facilities - S.P.I.F., Volume I and II, Management \& Industrial Research Publications, P.O. Box 7133, Kansas City, Missouri 64113, U.S.A., Phone (816) 444-6622.

Rinne, C. A., 1993, Hanford 200 Areas Development Plan, DOE/RL 92-29, Westinghouse Hanford Company, Richland Washington.

Reidel, S. P., 1996, Site Characterization and Environmental Baseline, WHC-SE-WMES-xxx, Westinghouse Hanford Company, Richland Washington.

Shord, A. L., 1996, Tank Waste Remediation System Privatization Phase I Site Evaluation Report, WHC-SD-WM-SE-023, Westinghouse Hanford Company, Richland, Washington.

Fort, D. L., 1996, Site Development Engineering Study, WHC-SE-TWRS-ES-003, ICF Kaiser Hanford Company, Richland Washington.

Shord, A. L., 1996, TWRS Privatization Phase I Site Development Project Definition Engineering Work Plan, WHC-SD-WM-WP-326 (Draft), Westinghouse Hanford Company, Richland, Washington.

Trost, E.T., 1996, Interoffice Memorandum, Tank Waste Remediation System Privatization Phase I, Former Grout Disposal Site Vendor Site Layout and Access Road Assessment Report, ICF Kaiser Hanford Company, Richland, Washington.

Ackerman, R.L., August 1996, Engineering Study, TWRS Privatization Phase I, Roads and Rail Systems Modifications, ICF Kaiser Hanford Company, Richland, Washington.

Williams, B. A., 1996, Monitoring Wells Engineering Study and Decommissioning Plan, WHC-SD-WM-ES-398, Westinghouse Hanford Company, Richland Washington.

Calmus, R. B., 1996, Solidified High-Level Waste Interim Storage Alternative Analysis and Path Forward Recommendation, WHC-SD-WM-SP-011, Westinghouse Hanford Company, Richland, Washington.

Burbank, D. A., 1996, Altematives Generation and Analysis Report for Immobilized Low-Level Waste Interim Storage Architecture, WHC-SD-W465-AGA-001, Westinghouse Hanford Company, Richland, Washington. 
Skoglie, D. E., 1996, Well Decommissioning Plan, WHC-SD-EN-AP-161, Rev. 0, Draft Appendix I, Fitness for Use Evaluation Recommendations for Hanford Site Wells, Engineering Change Notice \# 708153, Westinghouse Hanford Company, Richland Washington.

Fort, D. L., 1996, Raw and Sanitary Water Service Engineering Study, WHC-SE-TWRES-002, ICF Kaiser Hanford Company, Richland Washington.

Ackerman, R.L., August 1996, Engineering Study, TWRS Privatization Phase I, Roads and Rail Systems Modifications, ICF Kaiser Hanford Company, Richland, Washington.

Palit, A. N., August 1996, Engineering Study, Privatization Phase I, Liquid Effluent Transfer Systems, ICF Kaiser Hanford Company, Richland, Washington.

Singh G., 1996, Engineering Study for the Phase I Privatization Facilities Electrical Power, WHC-SE-WM-ES-393, Westinghouse Hanford Company, Richland Washington.

Palit, A. N., August 1996, Engineering Study, Privatization Phase I, Liquid Effluent Transfer Systems, ICF Kaiser Hanford Company, Richland, Washington. 

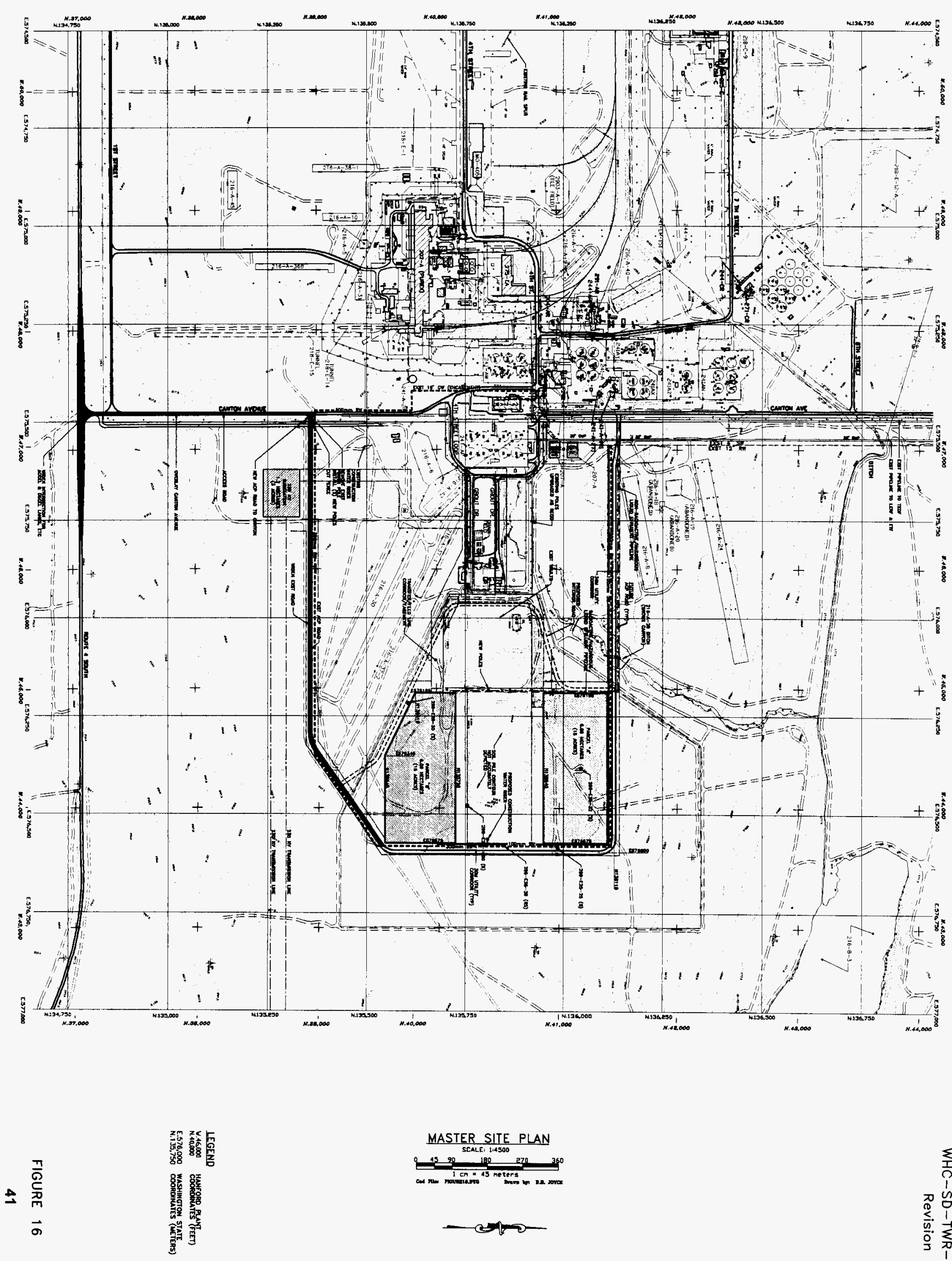


\section{DISTRIBUTION SHEET}

\begin{tabular}{|c|c|c|c|c|c|}
\hline To & \multirow{2}{*}{\multicolumn{3}{|c|}{$\begin{array}{l}\text { From } \\
\text { WHC TWRS Process Design } \\
\text { R. J. Parazin }\end{array}$}} & \multicolumn{2}{|c|}{ Page 1 of 1} \\
\hline Distribution & & & & \multicolumn{2}{|c|}{ Date $09 / 30 / 96$} \\
\hline \multicolumn{4}{|c|}{ Project Title/Work Order } & \multicolumn{2}{|c|}{ EDT No. 618857} \\
\hline TWRS Privati & r Site Plan & & & \multicolumn{2}{|c|}{ ECN No. N/A } \\
\hline \multicolumn{2}{|c|}{ Name } & $\begin{array}{c}\text { Text } \\
\text { With Al } \\
\text { Attach. }\end{array}$ & Text Only & $\begin{array}{l}\text { Attach./ } \\
\text { Appendix } \\
\text { Only }\end{array}$ & $\begin{array}{c}\text { EDT/ECN } \\
\text { Only }\end{array}$ \\
\hline
\end{tabular}

U.S. Department of Energy

Richland Operations office

N. R. Brown

T. R. Hoertkorn

W. F. Edwards

W. A. Rutherford

R. B. Simmons-Green

$\begin{array}{ll}K 6-51 & x \\ B 4-55 & x \\ A 2-45 & x \\ A 2-45 & x \\ S 7-53 & x\end{array}$

\section{ICF Kaiser Hanford Company}

D. L. Fort

J. T. Koberg

M. D. Rickenbach

E. F. Yancey

R. L. Ackerman

G3-12 $\mathrm{x}$

G3-12

Pacific Northwest National Laboratory

B. A. Reynolds

P7-19 $\mathrm{x}$

Westinghouse Hanford Company

P. Felise

J. S. Garfield

B4-55 $x$

K. A. Gasper

M. N. Islam

P. C. Miller

R. J. Parazin ( $(t)$

H5-49

G3-21

R3-08

R1-51

H5- 49

L. E. Thomas

R3-08

W. L. Adams

S5-13

A. L. Johnson

H6-20

$x$

$x$

$x$

$x$

A. L. Johnson

A3-88

$\mathbf{x}$

$x$

$x$

Central Files (original + 1)

x 